\title{
Phylogenetic relationships among subclades within the Trinity bristle snail species complex, riverine barriers, and re-classification
}

\author{
ROBERT M. SULLIVAN*
}

California Department of Fish and Wildlife, Region 1, Wildlife/Lands Program, P.O. Box 1185 Weaverville, California 96093

*Corresponding Author: robert.sullivan@wildlife.ca.gov

The Trinity bristle snail (Monadenia setosa) is listed as a threatened species under the California Endangered Species Act (CESA). In northern California, populations of this endemic terrestrial gastropod occur in rare, isolated, and highly fragmented locations within the greater Trinity Basin. Since 1952 when it was originally described, the taxonomic status of the Trinity bristle snail has been questioned based on unpublished information limited in geographic scope and sample size, which resulted in the taxon being reduced from species status (M. setosa) to subspecific status (M. i. setosa) within the Redwood sideband (M. infumata) species complex. Primary objectives of the present study were to: 1) use DNA extraction and PCR sequencing to gain insight into patterns of genetic variation and phylogenetic relationships among a larger sample of endemic populations of the Trinity bristle snail;2) re-evaluate the systematic and taxonomic status of the species using outgroup analysis and references samples from sympatric ecologically co-occurring taxa within the genus Monadenia; and 3) evaluate the potential biogeographic effects of major riverine systems on genetic differentiation among relic and disjunct populations within the Trinity Basin. Results of the DNA sequence analysis using several different tree reconstruction methods revealed that subspecies of the Redwood sideband ( $M$. i. subcarinata), Yellow-based sideband (M. i. ochromphalus), and the Trinity bristle (M. i. setosa) exhibited a phylogenetic signal at $\geq 95 \%$ species probability. Except for the Yellow-based sideband, molecular evidence detected the presence of several morphologically cryptic subclades within each species clade formerly undescribed by the scientific community. Syntopic ${ }^{1}$ ecological relationships between subclades of the Trinity bristle snail and the Redwood sideband occurred in several areas within the geographic range of the Trinity bristle snail, which indicated that these subclades were conservatively differentiated at the subspecific level. A Bayesian coalescent tree showed that genetic variation

\footnotetext{
${ }^{1}$ Syntopy refers to the joint occurrence of two species in the same habitat at the same time, which may result in hybridization between closely related taxa or sister species. In contrast, sympatric species occur together in the same region, but do not necessarily share the same localities as syntopic species do (Futuma 2009).
} 
among allopatric subclades of the Trinity bristle snail and the Redwood sideband were congruent with hydrological discontinuities associated with site-specific riparian stream corridors and the primary river systems within the Trinity Basin. Correlation analysis revealed a pattern of area effects, wherein sparsely bristled Trinity bristle snails were generally found to the northwest and more abundantly bristled individuals to the southeast in relation to primary river corridors that bisect the central Trinity Basin. A similar but opposite trend was observed in the directional pattern of banding. Here the most conspicuously banded individuals were found in samples distributed to the northwest while individuals with less conspicuous banding patterns occurred in a more southeasterly direction in relation to primary riverine corridors. These geographic patterns of bristles and bands appeared to reflect shallow clines that were evident in samples of both the Trinity bristle snail and the Redwood sideband. Parsimony character state reconstructions revealed that the presence of bristles and conspicuousness of bands was widespread among genetic samples, but these attributes did not provide a definitive morphological character that could be used to distinguish among co-occurring taxa.

Key words: biogeography, DNA sequence analysis, Monadenia setosa, northern California, phylogenetics, river systems, taxonomy, terrestrial gastropod, Trinity bristle snail

\section{Distribution and Status}

There are 284 species representing 30 families of land snails and slugs currently described as living within the geographic boundaries of California. Numerous additional species remain to be described, some recognizable only by use of modern DNA sequence analyses (Roth and Sadeghian 2006). The genus Monadenia consists of a diverse group of air-breathing land snails (gastropods) within the family Bradybaenidae ${ }^{2}$. Species within this genus are commonly referred to as "sidebands." Currently there are 14 species and 19 subspecies of terrestrial snails in the genus Monadenia within the geographic boundary of California that are primarily distributed from south-central California, on the west side of the Sierra Nevada, into the Cascade Mountains of southwestern Oregon (Roth and Sadeghian 2006).

The Trinity bristle snail ( $M$. setosa ${ }^{3,4}$ ) is a rare and rather large terrestrial forestdwelling gastropod (Fig. $1^{5}$ ) endemic to the greater Trinity Basin of northern California. Populations occur in isolated and highly fragmented locations within central Trinity County and extreme eastern Humboldt County (Fig. 2). Geographically, populations may be found along both sides of the western-most segment of the mainstem Trinity River, east slope of the New River gorge, South Fork Trinity River, Hayfork Creek, and along the east slope of South Fork Mountain on the Trinity-Humboldt county line (Fig. 2; Table 1).

\footnotetext{
${ }^{2}$ Phylum: Mollusca, Class: Gastropoda, Order: Stylommatophora, Family: Bradybaenidae, Genus: Monadenia, Species: Monadenia setosa.

${ }^{3} \mathrm{https}: / /$ wildlife.ca.gov/Conservation/Invertebrates

${ }^{4} \mathrm{https} / / /$ nrm.dfg.ca.gov/FileHandler.ashx?DocumentID=84011\&inline.

${ }^{5}$ https://onlinelibrary.wiley.com/cms/asset/0ff24ac9-31b6-4999-a249-470a29709e0d/jawr12774-fig-0004-m.jpg
} 


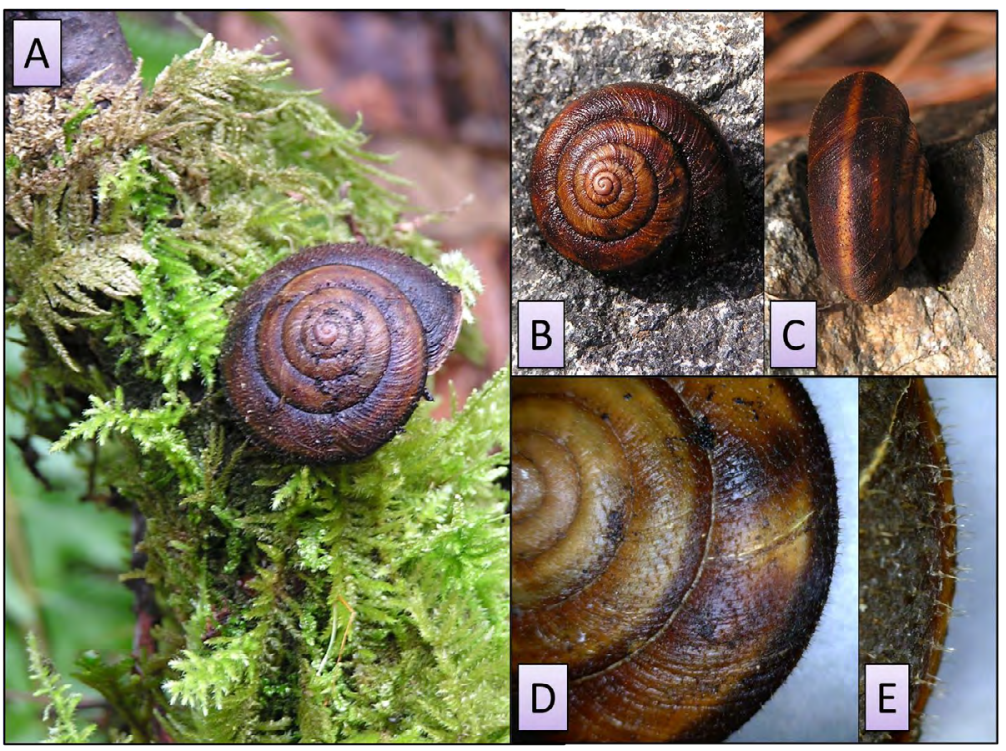

Figure 1. A) Trinity bristle snail ( $M$. setosa) on a decaying rain-soaked moss-covered tree branch at the Type locality at Swede Creek. B) dorsal and C) lateral side views of the surface of the shell showing striated surface topography of radiating impressed lines and ribs, lack of a conspicuous dull or subdued banding pattern, and (D and E) the minute hair-like bristles on the shell's thin periostracum that are brownish in color, and plump and conical in shape. Bristles may be worn off on old-aged (large) shells through abrasion but are generally visible by close examination with a hand-lens and can usually be re-hydrated on shells that are not too worn. Presence of these fine hair-like bristles covering the surface of the shell in live animals contribute to the "velvety" or "dirty" appearance when covered with specks of detritus.

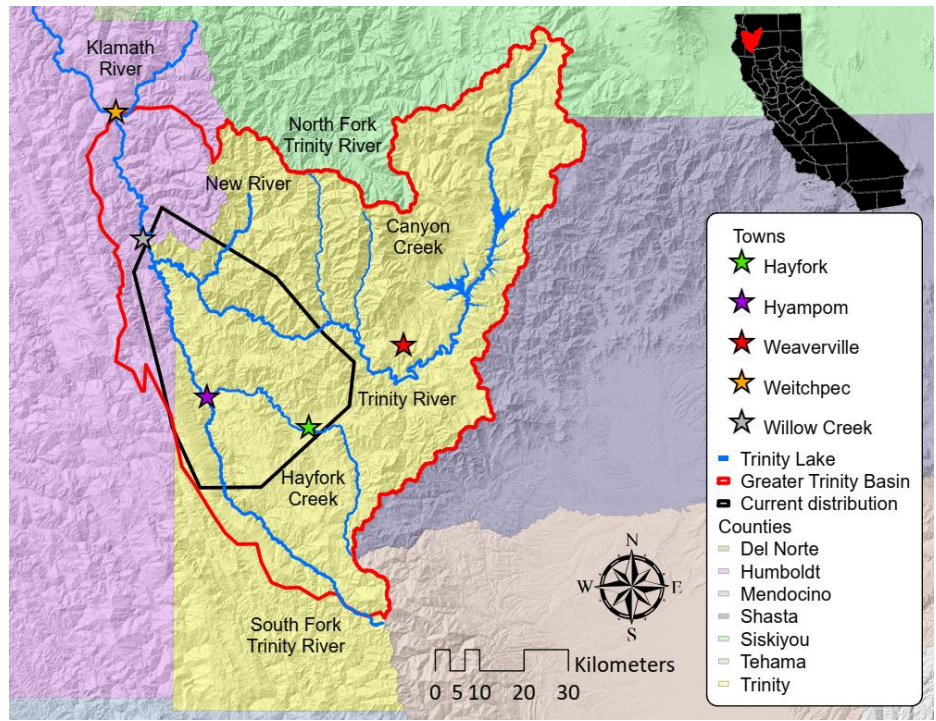

Figure 2. Current geographic distribution of the Trinity bristle snail (M. setosa) in Trinity County and eastern Humboldt County, showing topographic relief and distribution of major river systems referenced to towns in the Trinity Basin of northern California. 
Table 1. Boundary of polygon delineating the current geographic range of the Trinity bristle snail (Monadenia setosa) in the greater Trinity Basin.

\begin{tabular}{|c|c|c|}
\hline Location & UTM-east & UTM-north \\
\hline $\begin{array}{l}\text { CA, Trinity County, } 6.6 \mathrm{~km} \mathrm{NE} \text { of the town of Willow Creek, Waterman } \\
\text { Ridge, } 1.7 \mathrm{~km} \text { S Maple Spring. }\end{array}$ & 451911.8 & 4536580.2 \\
\hline $\begin{array}{l}\text { CA, Humboldt County, } 7.0 \mathrm{~km} \text { of the town of Willow Creek, Madden } \\
\text { Creek, } 0.7 \mathrm{~km} \text { W South Fork Trinity River. }\end{array}$ & 447236.1 & 4525208.2 \\
\hline $\begin{array}{l}\text { CA, Trinity County, } 4.6 \mathrm{~km} \text { E of the town Mad River, } 0.6 \mathrm{~km} \mathrm{~S} \text { Miller } \\
\text { Spring, } 1.2 \mathrm{~km} \text { N Lamb Gap, South Fork Mountain Road. }\end{array}$ & 461034.2 & 4477304.9 \\
\hline $\begin{array}{l}\text { CA, Trinity County, } 8.5 \mathrm{~km} \mathrm{~N} \text { of the town of Forest Glen, } 0.4 \mathrm{~km} \mathrm{~S} \\
\text { Bear Wallow Meadow. }\end{array}$ & 470447.9 & 4477240.1 \\
\hline $\begin{array}{l}\text { CA, Trinity County, } 8 \mathrm{~km} \text { NE of the town of Hayfork, Baker Creek, } 4.1 \\
\text { km NW Big Creek Ranch. }\end{array}$ & 490809.1 & 4494134.9 \\
\hline $\begin{array}{l}\text { CA, Trinity County, } 6.9 \mathrm{~km} \mathrm{SW} \text { of the town of Junction City, } 0.5 \mathrm{~km} \\
\text { SW Soldier Creek. }\end{array}$ & 492538.4 & 4502894.7 \\
\hline $\begin{array}{l}\text { CA, Trinity County, } 7.5 \mathrm{~km} \mathrm{NE} \text { of the town of Del Loma, } 1.9 \mathrm{~km} \mathrm{NW} \\
\text { Cherry Flat and French Creek. }\end{array}$ & 474522.3 & 4521649.3 \\
\hline $\begin{array}{l}\text { CA, Trinity County, } 9.1 \mathrm{~km} \mathrm{NE} \text { of the town of Forest Glen, } 0.8 \mathrm{~km} \mathrm{SE} \\
\text { Big Flat of Naufus Creek. }\end{array}$ & 473434.3 & 4478230.0 \\
\hline $\begin{array}{l}\text { CA, Trinity County, } 4.9 \mathrm{~km} \mathrm{SW} \text { of the town of Helena, south side Trin- } \\
\text { ity River, } 2.9 \mathrm{~km} \text { NW Squaw Camp Spring, } 0.5 \mathrm{~km} \text { SE Eagle Creek. }\end{array}$ & 487366.6 & 4509143.0 \\
\hline CA, Trinity County, $1.0 \mathrm{~km} \mathrm{SW}$ town of Dailey, Bell Creek tributary. & 462418.3 & 4527703.0 \\
\hline
\end{tabular}

In 1972, Roth included the species on a list of rare and potentially endangered land snails (Roth 1972). This taxon was one of the first species of terrestrial gastropods proposed as Threatened under the Endangered Species Act (USFWS 1973, Federal Register, 41: 17742, 28 April 1976). In 1980, the California Department of Fish and Wildlife (CDFW) listed this species as "rare," and in 1984, it was reclassified as "threatened" under the California Endangered Species Act (CESA; CDFW 1972). The species subsequently became a Category 2 ("C2") Federal Candidate Species in November 1994 (Federal Register, 59: $58,982,58,983)^{6}$; a category later eliminated. ${ }^{7}$ Also in 1994, the Trinity bristle snail was included as an "Additional Species" in the Northwest Forest Plan covering late-successional and old-growth forests in the range of the northern spotted owl (Strix occidentalis caurina; USFS and USBLM 1994). The International Union for Conservation of Nature Red List of Threatened Species lists the Trinity bristle snail as "Vulnerable" (VU) (Groombridge 1994; Baillie and Groombridge 1996; Roth 1996) ${ }^{8}$. NatureServe assigned the Trinity bristle snail the range-wide global rank of "G2T1" for critically imperiled taxa with a high risk of extinction or elimination due to restricted range, few populations or occurrences, steep declines, and severe threats. Currently, the Trinity bristle snail is the only species of terrestrial gastropod in California listed under CESA.

\footnotetext{
${ }^{6}$ Available from: https://ecos.fws.gov/docs/federal_register/fr2729.pdf

${ }^{7} \mathrm{C} 2$ category defined as taxa "for which information now in the possession of the United States Fish and Wildlife Service (USFWS) indicates that proposing to list as endangered or threatened is possibly appropriate, but for which persuasive evidence on biological vulnerability and threat are not currently available to support proposed rules" (Federal Register, 59: 58,982, 58,983, 15 November 1994. In 1996 the USFWS published a notice making a final decision to eliminate the C2 List (61 Federal Register, 61:64,481, 5 Dec. 1996).

${ }^{8}$ https://dx.doi.org/10.2305/IUCN.UK.1996.RLTS.T13666A4324507.en.
} 


\section{Background}

The Trinity bristle snail was hypothesized to be a relict species of the Pleistocene epoch when climatic conditions were much cooler and forest conditions more mesic than today (Talmadge 1952; Dunk et al. 2004). Populations occur within Klamath mixed-conifer forests along riparian corridors and in adjacent upland habitats characterized by a mesic deciduous hardwood understory. Although mostly observed within moist, well-drained and shaded canyons or within riparian stream-side benches covered with a thick layer of leaf mold, isolated populations also occur in drier upland mixed conifer habitat with adequate canopy cover (Sullivan 2021). Depending on weather conditions, the Trinity bristle snail is most active from May through October, and generally observed between dusk and dawn, when the air temperature is cooler and more humid. The species is active during the day, particularly after several days of warm spring or late fall weather associated with fog and saturating rains (Sullivan 2021; Fig. 3).

In 1952, Robert R. Talmadge, a Pacific Gas and Electric employee and amateur naturalist residing at Willow Creek, Humboldt County, California, described the Trinity bristle snail as a new species (Talmadge 1952). The type locality was described based on specimens found along the lower reach of Swede Creek, Trinity County, a small tributary draining into the Trinity River along the northeast side of Highway 299 (Topotype: $40.793^{\circ} \mathrm{N}$, $123.355^{\circ} \mathrm{W}$ ). Where along Swede Creek these specimens were found was not specifically identified. Twenty-six years later Roth (1978) performed a contract study for the United States Forest Service (USFS) and surveyed adjacent tributaries to the Trinity River from Italian Creek to Manzanita Creek, all in Trinity County. This effort focused on delineating the range and habitat associations of the species (Armijo 1979). Results of this investigation showed that extant populations of the Trinity bristle snail were present within riparian vegetation in Swede Creek, and along the lower riparian drainages of Little Swede Creek and Big French Creek based on samples of empty shells. Roth and Eng (1980) published results of their 1978 field study and added the first published photographs of a shell from the Trinity bristle snail, along with figures describing external anatomy and elements of the reproductive system. They concluded that the species was rare within its range with no evidence of expansion or restriction of its geographic distribution within historical times.

In 1986, Roth reported results of a second and more extensive field investigation conducted from 1981 to 1982 (Roth 1982; Roth and Pressley 1986); which expanded the area of consideration to include Big French Creek and regions of potential suitable habitat on the south side of the Trinity River, subsidiary drainages south to Hayfork Creek, and drainage divides north of Swede Creek and Big French Creek. This effort also extended the known range of the Trinity bristle snail to the north, east, and south of its previous geographic range, including Ripstein Campground, north of Junction City (on the NE), Hawkins Creek (on the NW), Hyampom (on the SW), and Hayfork Summit (on the SE). Additional surveys were also conducted along Hayfork Creek as far south as the Natural Bridge Picnic Area $\left(123^{\circ} 00^{\prime}-123^{\circ} 30^{\prime} \mathrm{W}\right.$ longitude by $40^{\circ} 37.5^{\prime}-40^{\circ} 52.5^{\prime} \mathrm{N}$ latitude).

From 1999 to 2002, surveys conducted by the USFS (Shasta-Trinity National Forest, Survey and Manage Program) found Trinity bristle snails at several new locations within Trinity County but retained no reference samples by location for verification purposes. From 2008 to 2011 Green Diamond Resource Company surveyed the environmental study limits associated with several timber harvest plans and CDFW listed species incidental take permits along the eastern slope of South Fork Mountain near Hyampom (eastern Humboldt and 


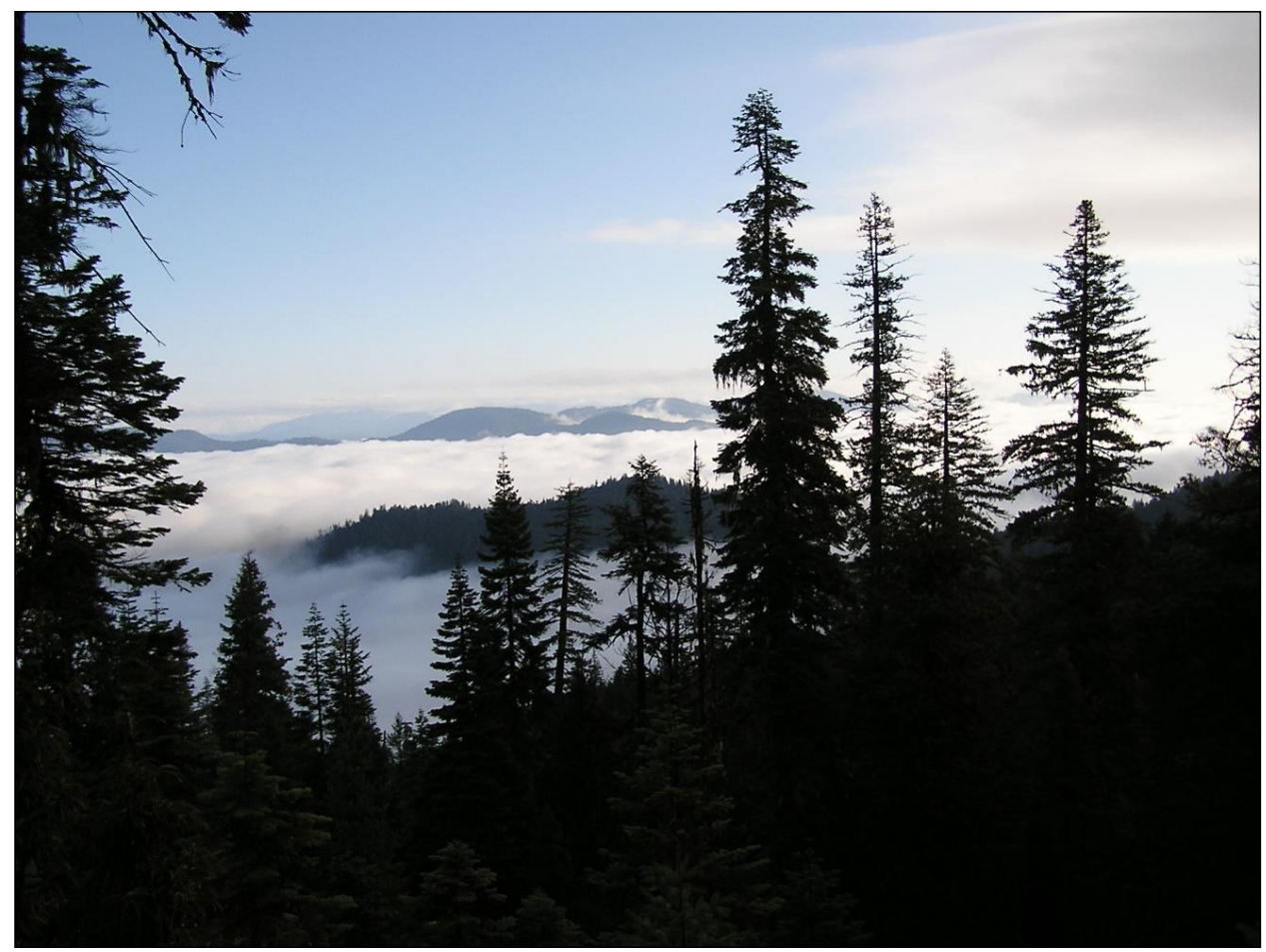

Figure 3. View from Hay Fork Mountain on the divide between extreme eastern Humboldt county and extreme western Trinity County looking northeast into the fog-belt of the greater Trinity Basin, which includes the bulk of the geographic distribution of the Trinity bristle snail (M. setosa). Moisture provided by the presence of this "fogbelt" is likely very important in providing the mesic forest conditions in association with saxicolous riparian and upland microhabitats for this species and other terrestrial gastropods found throughout the region.

western Trinity counties). These surveys also resulted in additional samples of the Trinity bristle snail, but they too lacked published systematic reference samples and photographs. The above surveys summarized all known information on the geographic range of Trinity bristle snail at that time.

Throughout most of the history of its investigation the Trinity bristle snail was considered a distinct species (Talmadge 1952). Recently the taxonomic validity of the designation "species" has been questioned based upon unpublished information narrow in geographic scope and sample size, including: 1) anecdotal and qualitative observations of several shells in which the "base was smooth and glossy rather than matte and covered with minute bristles," which lead to the hypothesis of morphological intergrades between the Redwood sideband and the Trinity bristle snail along the western margin of the range of the Trinity bristle snail (Roth and Eng 1980; Roth and Pressley 1986); and 2) DNA-sequenced data from only two specimens sampled from throughout the greater Trinity Basin (Cordero and Lindberg 2002). From these data it was concluded that: 1) the Trinity bristle snail was a subspecies of the Redwood sideband, hence the name M. i. setosa, with setosa as the specific epithet for the type specimen; and 2) the Trinity bristle snail was part of a large interbreeding complex forming a continuum with other populations of Monadenia distributed throughout the greater 
Trinity Basin, a conclusion incorporated into the most recent taxonomic classification of species and subspecies within the genus Monadenia (Roth and Sadeghian 2006).

\section{Objectives}

Specific objectives of the current research were four-fold.

- First, update knowledge on the geographic distribution of the Trinity bristle snail in the Trinity Basin of Northern California.

- Second, sample representative locations throughout the known geographic range of the species, collect representative shells and tissue samples, and re-inventory populations at and near the type locality and other areas of potential occurrence that historically were poorly.

- Third, re-evaluate the systematic status and taxonomic classification of the Trinity bristle snail using molecular phylogenetic outgroup analyses, reference samples from co-occurring taxa, and geographically disjunct populations of Trinity bristle snails.

- Fourth, evaluate the potential biogeographic effects of hydrological and topographic discontinuities within the Trinity Basin on genetic differentiation among allopatric relic populations.

\section{METHODS}

\section{Study Area}

Representative samples of tissues and shells were obtained and evaluated from throughout the known geographic range of the species (Sullivan 2021). Surveys focused on geographic regions throughout the northwestern segment of the Trinity River and its tributaries in Trinity and Humboldt counties based on previous field surveys (Talmadge 1952; Walton 1963; Roth 1978; Roth and Eng 1980), including: 1) the Type Locality and areas nearby (Italian, Manzanita, Swede, Big, French, Price, Bidden, Limestone, and Little Swede creeks, an unnamed creek south of Big Bar, south side of Trinity River east of Price Creek, Trinity County); 2) areas of potential occurrence based on quantitative suitable habitat descriptions not yet surveyed; 3 ) populations and habitats associated with recent timber harvests; 4) isolated locations along the Trinity River, South Fork of the Trinity River, and Hayfork Creek; 5) several new locations near South Fork Mountain (Trinity Co. and Humboldt Co. lines) from Blake Mountain west of Hyampom, south to Norse Butte, and east to near Forest Glen; and 6) hypothesized contact and "hybrid" zones between the Trinity bristle snail and the Redwood sideband (Roth and Pressley 1986).

\section{Survey Methods}

Field surveys focused on known ecological and microhabitat descriptions of "critical" and potential suitable habitat based on historical accounts (Talmadge 1952; Roth 1978; Roth and Eng 1980). Survey efforts were facilitated in many areas as shells of Trinity bristle snails often washed or drifted down from suitable habitat at higher elevations onto wellworn deer trails, catchments, or other depressions that prevented their scattering or crossing fragmented talus or boulder fields (Sullivan 2021). Live and active Trinity bristle snails were sampled during warm wet, foggy, or rainy conditions during the months of March, April, 
May, September, and October. During colder winter or more arid summer months, inactive live specimens were found sealed in their excavated subterranean estivation chambers well below the ground or substrate surface (Sullivan 2020).

\section{Statistical and Morphological Analyses}

All statistical tests were performed used the R-suite of statistical programs (v4.0.2, R Core Team 2020). Principal components analysis (PCA) using singular value decomposition 9 of the centered data matrix described variation, discarded redundant variables, examined the extent of association among morphological, ecological, and genetic attributes of terrestrial gastropods, and assessed the ability of attributes to explain variation among samples (Smartt and Sullivan 1990; Sullivan and Smartt 1995; Sullivan 1996, 1997, 2020). Component axes that accounted for $>1 \%$ of the total variation in "attribute space" were retained for further analysis. This method is generally preferred for numerical accuracy as resulting principal components are orthogonal, thus minimizing multicollinearity between model predictors, with the goal of identifying a smaller subset of variable components that capture the majority of variance in predictors (Everitt and Hothorn 2011). Nonparametric Spearman's rank correlation $\left(r_{s}\right)$ 2-tailed test was used to calculate the strength and direction of the relationship between any two variables expressed as a monotonic relationship, whether linear or not (Corder and Foreman 2014). P-values were adjusted using the Benjamini-Hochberg method (Benjamini and Hochberg 2000; Machiwal and Madan 2006); levels of significance were evaluated at $\mathrm{p}=0.05=*, 0.01=* *$, and $0.001=* * *$.

Abundance of periostracal bristles (henceforth called "bristles") on the shell's thin periostracum "skin" of live snails was ranked as: none $=1$, sparse $=2$, or abundant $=3$. Similarly, conspicuousness of bands was ranked as: slightly conspicuous $=1$, moderately conspicuous $=2$, or highly conspicuous $=3$. Designations of river-side (east vs. west) were ranked from: 1 =W-side Trinity River and E-side South Fork Trinity River, 2 = W-side Trinity River and W-side South Fork Trinity River, 3 = NE-side Trinity River and NW-side New River, 4 = W-side Trinity River, E-side Hayfork Cr, NE-side South Fork Trinity River, $5=$ NE-side Trinity River and NE-side South Fork Trinity River, $6=$ W-side Trinity River and W-side Klamath River, and $7=\mathrm{W}$-side Trinity River and E-side Klamath River. Parallel ranking of designated watersheds and adjacent riparian stream (creek) corridors ranged 1 to 15 and 1 to 18 , respectively.

\section{Molecular Methods}

Sampling methods.-From 333 geo-referenced sites throughout the known range of the Trinity bristle snail a representative sample of 61 adult specimens were used in the DNA analysis. An attempt was made to obtains a sample of five specimens per location, but the exact number depended on site-specific availability. Typically, sample sizes for molecular biodiversity assessment using DNA range from five to ten individuals per species, although one or two specimens is not uncommon since these are often the only representatives available (Phillips et al. 2019). For the DNA analyses live snails were placed in ventilated plastic

\footnotetext{
${ }^{9}$ Singular Value Decomposition (SVD) is a linear algebra computational method frequently used to calculate principal components for a dataset in a more efficient and numerically robust way (https://en.wikipedia.org/wiki/ Singular_value_decomposition).
} 
containers with screw tops and a small amount of moist leaf litter along with a collection number and site coordinates (UTM-east, UTM-north). Samples were brought back to the laboratory where each snail was rinsed in cold distilled water and tissue samples from the foot appendage taken and immediately placed in capped glass containers containing $95 \%$ ethanol. Sampling of tissue was conducted under extreme sanitary condition to prevent cross-contamination of samples. European outgroup sequences were obtained online from GenBank $^{10}$.

DNA extraction, PCR, and Post-PCR and sequencing.--Samples were assayed at the University of California Davis Department of Animal Science Genomic Variation Laboratory without knowledge of the taxonomy or location of the geographic sample. DNA was extracted from ethanol-preserved foot tissue samples including replicates where more multiple tissues were preserved per vial. The DNA extraction procedure followed the manufacturer's protocol for the Gentra Puregene DNA extraction kit. We used Polymerase Chain Reactions (PCR) to amplify the cytochrome oxidase I gene (COI) as this gene has proved useful at delimitating other snail species. Initial PCR reactions were carried out using universal LCO1490, 5-GGTCAACAAATCATAAAGATATTGG-3 and HCO2198 5-TACTTCAGGGTGACCAAAAAATCA-3 primers (Palumbi 1996; Kocher et al. 1989; GoTaq ${ }^{\circledR}$ Flexi Buffer, Promega Corporation, Fitchburg, WI), and a $2.5 \mathrm{mM}$ concentration of each DNTP and $25 \mathrm{mM} \mathrm{MgCl}_{2}$. Internal primers were designed that had an additional ACA on the 3' end of LCO and TTT on the 3' end of HCO following initial sequencing of samples that did not sequence during the first round of sequencing. A touch down protocol was used at $54^{\circ} \mathrm{C}\left(129.2^{\circ} \mathrm{F}\right)$ for the first 4 cycles at 2 minutes with $72^{\circ} \mathrm{C}\left(162.6^{\circ} \mathrm{F}\right)$ extension for $2: 30$ minutes, followed by $52^{\circ} \mathrm{C}\left(125.6^{\circ} \mathrm{F}\right)$ annealing for 4 cycles with $72^{\circ} \mathrm{C}\left(162.6^{\circ}\right.$ $\mathrm{F})$ extension for 2 minutes, with subsequent 26 cycles at $48^{\circ} \mathrm{C}\left(118.4^{\circ} \mathrm{F}\right)$ annealing for 30 seconds and $72^{\circ} \mathrm{C}\left(162.6^{\circ} \mathrm{F}\right)$ extension for 2 minutes, and finally a 5 minute $72^{\circ} \mathrm{C}\left(162.6^{\circ}\right.$ F) extension step followed by a $10^{\circ} \mathrm{C}\left(50.0^{\circ} \mathrm{F}\right)$ hold. This protocol has worked well with other invertebrates and proved reliable in this situation. Cleanup of post-PCR sequencing was performed using Agencourt Ampure Magnetic Beads (Beckman Coulter Scientific). Cycle sequencing protocol used Big-Dye Terminator 3.1 (Applied Biosystems). Sequencing was performed using ethanol precipitation followed by suspension in double distilled water and sequenced on an Applied Biosystems 3730xl DNA unit.

Phylogenetic tree reconstruction, and molecular species delimitation.-Sequences were aligned using the MUSCLE alignment tool (Edgar 2004), where alignment contained 83 unique samples with 656 base pairs (bp) of genetic data. Alignment was visualized using the program Mesquite v.3.61 (Maddison and Maddison 2019) and phylogenetic trees were reconstructed using three methods. First, MrBayes v. 3.2.1 (Ronquist et al. 2012), which jointly calculates both the distance and nucleotide substitution models that best fit tree reconstructions. The maximum-credibility method evaluates each of the sampled posterior trees. Each clade within the tree was given a score based on the fraction of times that it appears in the set of sampled posterior ${ }^{11}$ trees (Drummond and Rambaut 2019). The product of these scores equates to the tree's score (Rambaut et al. 2018). The tree with the highest score was

\footnotetext{
${ }^{10}$ https://www.ncbi.nlm.nih.gov/genbank/

${ }^{11}$ A maximum clade credibility tree summarizes results of a Bayesian phylogenetic inference. Whereas a majority-rule tree combines the most common clades to yield a tree that was not sampled in the analysis, the maximumcredibility method evaluates each sampled posterior tree. Each clade within the tree is given a score based on the fraction of times that it appears in the set of sampled posterior trees, and the product of these scores is the tree's score. The tree with the highest score is then the maximum clade credibility tree.
} 
considered the maximum clade credibility tree. A total of $20 \times 106 \mathrm{MCMC}$ generations were completed by the program MrBayes followed by a 50\% majority rule consensus tree reconstruction. Second, the Randomized Axelerated Maximum Likelihood (RAxML) Blackbox interface program was used to efficiently infer trees for extremely large datasets, either in terms of the number of taxa or the sequence length (Liu et al. 2011; Stamatakis 2014). For RAxML the nucleotide substitution model chosen was the General Time Reversible (GTR; Tavaré 1986). Third, a Bayesian Coalescent tree was reconstructed using the program BEAST v1.7.5 where the coalescent functioned as a model of the distribution of gene divergence in a genealogy (Drummond and Rambaut 2007; Drummond and Suchard 2010; Liang et al 2015). Bayesian inference was based on the posterior probability distribution approximated by a sample of species trees generated from a Markov Chain Monte Carlo (MCMC) algorithm. The substitution model used was HKY for codons 1 and 2 and GTR with gamma rate variation for codon position 3 (Hasegawa et al. 1985). An uncorrelated relaxed clock was used for the scaled mutation rate. The MCMC chain ran for $119 \times 106$ generations. For all datasets, tree construction (phylogram) and labeling were done using the FigTree Drawing Tool software (v1.4.4; Rambaut 2009). Parsimony character state reconstructions were done using the Bayesian Coalescent tree reconstructed using the program BEAST for: 1) bristle abundance, 2) band conspicuousness, 3) watershed designation, 4) river-side, and 5) adjacent stream corridor designation for each genetic sample using the program Mesquite. Species were delimitated based on the Bayesian General Mixed Yule Coalescent ${ }^{12}$ procedure using the program bGMYC (Reid and Carstens 2012; Talavera et al. 2014), which accounts for uncertainty in the phylogeny. Generally, the program bGMYC tries to detect the shift in branching pattern from a Yule process, characteristic of intraspecific variation, to a birth-death process more characteristic of interspecies variation. The top 100 trees that had the highest posterior probability from the BEAST analyses were used to estimate the mitochondrial DNA (mtDNA) species delineations.

\section{RESULTS}

\section{Geographic Distribution of DNA Samples: Morphologic and Ecological Attributes}

Correlation analysis. - Correlation analysis indicated a significant negative relationship between the abundance of bristles and the conspicuousness of bands on the surface of shells in the individual generic samples (Table 2). The correlation between the abundance of bristles and the distribution of river-side, watershed, and riparian stream corridor was either not significant or significantly negative. Yet conspicuousness of bands showed a significant positive correlation with all three hydrological variables. As expected, there was a significant correlation between designated watersheds and adjacent riparian stream corridors given the parallel distribution and diversity in both hydrological features. Although the geographic relationship between river-side and riparian stream corridor was significant, there was no correlation between river-side and placement of watershed boundaries.

Bristle abundance was significantly correlated with UTM-east $\left(\mathrm{r}_{\mathrm{s}}=0.83, \mathrm{p}=0.001, \mathrm{n}\right.$ $=69$ ) but negatively correlated with UTM-north $\left(r_{s}=-0.55, p=0.001, n=69\right)$, suggesting a

\footnotetext{
${ }^{12}$ The GMYC method classifies branches in a gene tree as intra- or interspecific by maximizing the likelihood of a GMYC evolution model. Branching events between species are modeled with a Yule model, which assumes a constant speciation rate and no extinction (Nee, May, and Harvey 1994; Barraclough and Nee 2001), and branching events within species are modeled using a neutral coalescent process (Hudson 1990).
} 
general northwest-to-southeast distribution in accordance with the opposite prevailing flow of the Trinity River, South Fork of the Trinity River, and Hayfork Creek, which bisect this section of the greater Trinity Basin. Sparsely bristled individuals were generally found to the northwest and more abundantly bristled snails to the southeast compared to mainstem river corridors (Fig. 4). In comparison, conspicuousness of bands was significant and positively correlated with UTM-north $\left(\mathrm{r}_{\mathrm{s}}=0.58, \mathrm{p}=0.001, \mathrm{n}=69\right)$ and negatively correlated with UTM-east $\left(\mathrm{r}_{\mathrm{s}}=-0.39, \mathrm{p}=0.001, \mathrm{n}=69\right)$. This distribution pattern indicated a general northwest-to-southeast distribution, with the most conspicuous bands observed on snails to the northwest and less conspicuous bands being found on individuals to the southeast of bisecting rivers systems, just the opposite from the pattern of abundance in bristles. Importantly, genetic samples of $M$. setosa and $M$. infumata showed the same clinal trends in the morphology of the shell for both bristle abundance and band conspicuousness.

Principal components analysis.-Components analysis of the morphologic and geographic attributes associated with the distribution of genetic samples accounted for

Table 2. Spearman rank correlation coefficient $\left(r_{s}\right)$ matrix among morphological and hydrological geographic attributes associated with each location/site where genetic samples $(n=69)$ were obtained within the known range of the Trinity bristle snail (Monadenia setosa). Correlations coefficients are below the diagonal and P-values are above the diagonal. P-values: $0.05=*, 0.01=* *, 0.001=* * *$.

\begin{tabular}{lclllc}
\hline Variable & Bristles & Bands & River-side & Watershed & Riparian stream corridor \\
\hline Bristles & 1.000 & 0.001 & 0.860 & 0.045 & 0.065 \\
Bands & $-0.380^{* * *}$ & 1.000 & 0.000 & 0.009 & 0.001 \\
River-side & 0.020 & $0.550^{* * *}$ & 1.000 & 0.080 & 0.002 \\
Watershed & $-0.240^{*}$ & $0.310^{* *}$ & 0.210 & 1.000 & 0.000 \\
Riparian & -0.220 & $0.390^{* * *}$ & $0.360^{* *}$ & $0.970^{* * *}$ & 1.000 \\
stream corridor & & & & & \\
\hline
\end{tabular}

93.5\% of the variation among collection sites on the first three PC's (Table 3). Individuals sampled with comparatively abundant bristles generally were negatively distributed along PC I (51.6\%) and positively distributed along PC II (21.8\%). Individuals with no bristles were generally positively distributed along PC I and negatively distributed along PC II (Fig. $5 \mathrm{~A})$. Individuals with comparatively few bristles split the difference along both vectors and there was no overlap in the ranking of bristle abundance among the three groups. In contrast, conspicuous of bands on the surface of the shell showed considerable overlap between snails. Ranked categories of slightly and moderately conspicuous bands plotted mostly neutral or negative along PC I (Fig. 5B) compared to samples with highly conspicuous bands, which plotted positive along this vector and separate from all other samples. As indicated in plots of bristles and bands, the distribution of river-side, watershed, and riparian stream corridor plotted positive along PC I. On PC III (20.1\% of the variation explained) watershed and riparian stream corridors had negative component loadings, while all other attributes loaded positive along this vector (Table 3 ). Vector trajectories of bristles and bands were opposite in direction as evidenced by their component loadings, which complemented the subtle patterns of "clinal" variation in shell morphology (Fig. 4). 


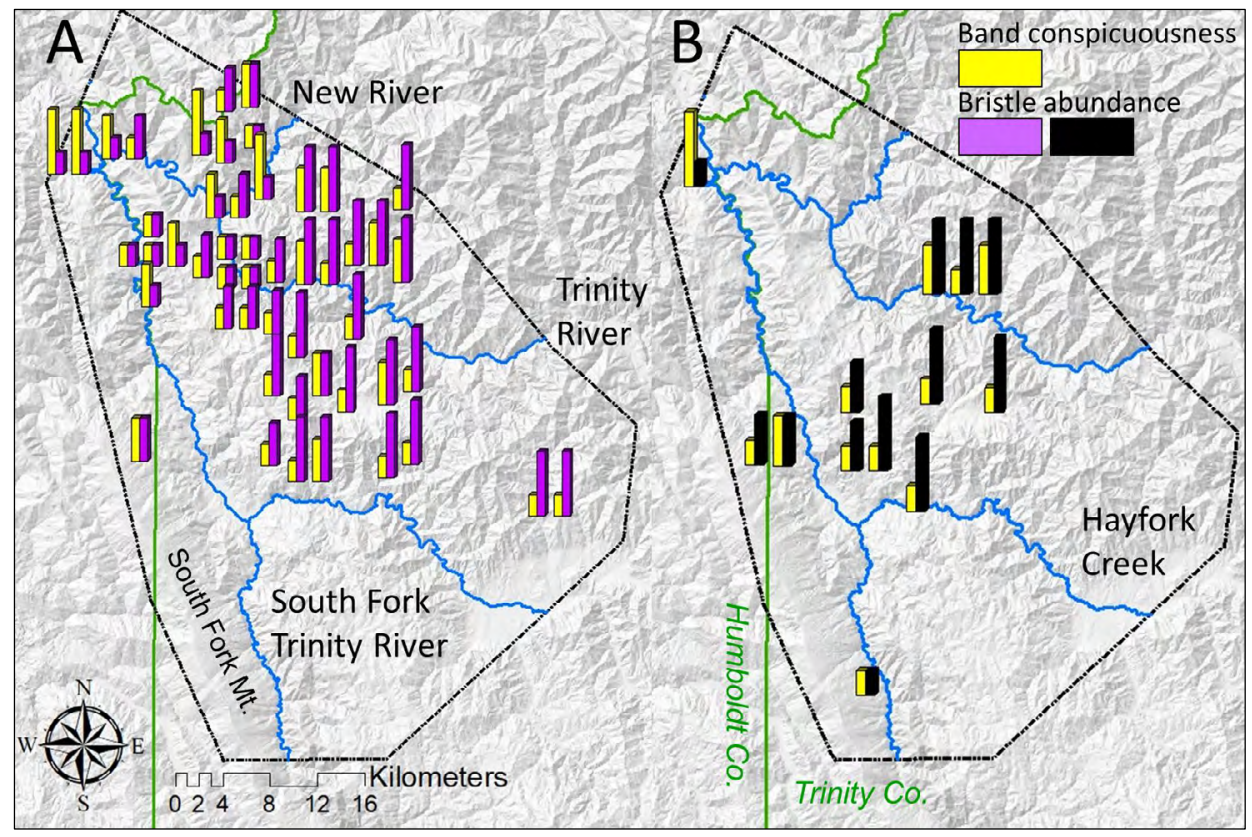

Figure 4. Map and 3-D bar graphs of the geographic distribution of genetic samples of A) the Trinity bristle snail and B) the Redwood sideband in showing the abundance of bristles compared to the conspicuousness of bands found on the surface of the shell overlaid onto the hydrological distribution of major river systems and topographic diversity of the landscape in the Trinity Basin. Paired bar graphs represent ranks $(1-3)$ that each snail had for bristle abundance (pink or black bars) or band conspicuousness (yellow bars); no snail had a 3:3 ranking of bristles to bands.

Table 3. Principal components (PC) analysis of morphological and hydrological attributes associated with locations where genetic samples $(n=69)$ were obtained within the known range of the Trinity bristle snail (Monadenia setosa). The proportion of variance explained refers to how much of the total variance is explained by each of the PCs with respect to the whole (the sum).

\begin{tabular}{lccc}
\hline Results of the analysis & PC I & PC II & PC III \\
\hline \multirow{2}{*}{ Variance } & Variance explained & & \\
Percent variance explained & 2.69 & 1.09 & 1 \\
& $51.6 \%$ & $21.8 \%$ & $20.1 \%$ \\
Abundance of bristles & Component loadings & & \\
Conspicuousness of bands & -0.418 & 0.845 & 0.207 \\
River-side & 0.717 & -0.393 & 0.443 \\
Watershed & 0.612 & 0.293 & 0.674 \\
Riparian stream corridor & 0.820 & 0.264 & -0.490 \\
\hline
\end{tabular}




\section{Phylogenetic Analysis and Tree Construction}

There was nearly complete congruency between the three phylogenetic tree reconstruction methods used in the DNA analysis among outgroups and samples of Trinity bristle snails from Trinity and Humboldt counties. The cophenetic correlation coefficient ${ }^{13}$ between the MrBayes tree (Fig. 6) and the RAxML tree (Fig. 7) was $81.0 \%$ and all major clades matched except for the tree backbone, which was a polytomy among the many Trinity bristle snail clades compared to a poorly supported but resolved tree produced by the RAxML reconstruction method. Among clades, $75.0 \%$ were identical except for the backbone of the RAxML tree, versus a polytomy for the backbone in the MrBayes tree. Results from BEAST tree (Fig. 8) were similar, producing an essentially identical topology as the RAxML tree, which indicated that the tree topology was robust. Topological robustness was also echoed by congruency between the three phylogenetic reconstruction methods used.

Out-group comparisons.-As expected, all rooted and un-rooted trees generated from the DNA sequence analysis showed that selected European out-group taxa: 1) Roman or Burgundy snail (Helix pomata), 2) Lapidary snail (Helicigona lapicida), and 3) White garden snail (Theba pisana) exhibited very different evolutionary relationships among themselves. This was also evident among taxa found regionally, including: 1) Church's sideband ( $M$. [Shastelix] churchi), 2) Sierra sideband (M. mormonum), 3) Columbia oregonian (Cryptomastix hendersoni), 4) Karuk hesperian (Vespericola karokorum), 5) Big Bar hesperian (Vespericola pressleyi), and 6) Beaded lancetooth (Ancotrema sportella). The Beaded lancetooth and species within the genus Cryptomastix appeared very divergent compared to other taxa within the in-group. Also, evident was a divergent sister-group relationship between subsamples of the Big Bar hesperian and the Karuk hesperian.

Rotating DNA-derived phylograms by re-rooting with any of the three European outgroup species did not change any of the relationships among species or subclades within the genus Monadenia. All DNA-derived phylograms indicated that the genus Monadenia represented a monophyletic clade with samples of both the Sierra sideband and Church's sideband diverging significantly from all other taxa within the genus Monadenia. Evidence from each of the phylograms (Figs. 6 - 9) also showed that the Church's sideband shares a more recent common ancestor (less genetically divergent "sister taxon") with the Monadenia in-group samples compared to the Sierra sideband. Because Cordero and Lindberg (2002) used both the Sierra sideband and Church's sideband as outgroups simultaneously, their sister-group affinities compared to their "bristled" in-group clade (B-group) were unresolved (Appendix I). Nevertheless, without resolution of the phylogenetic sister-taxon relationships between these two species, Roth and Sadeghian (2006) assigned the Sierra sideband and Church's sideband to the subgenera Corynadenia and Shastelix, respectively.

\section{Variation among Clades and Polytomous Subclades}

Clades and species within the in-group.-The DNA-derived BEAST consensus tree with cartooned (triangled) clades provided the basis for delineating molecular affinities among species and subclades of large, banded forest snails within Trinity and Humboldt counties (Fig. 9). The bGMYC analysis was used as a guide to the phylogenetic delimitation of new species clades. Clades shaded with yellow had $95.0 \%$ probability of being a species

13 A measure of how faithfully a tree (phylogram) preserves the pairwise distances between the original unmodeled data points. 


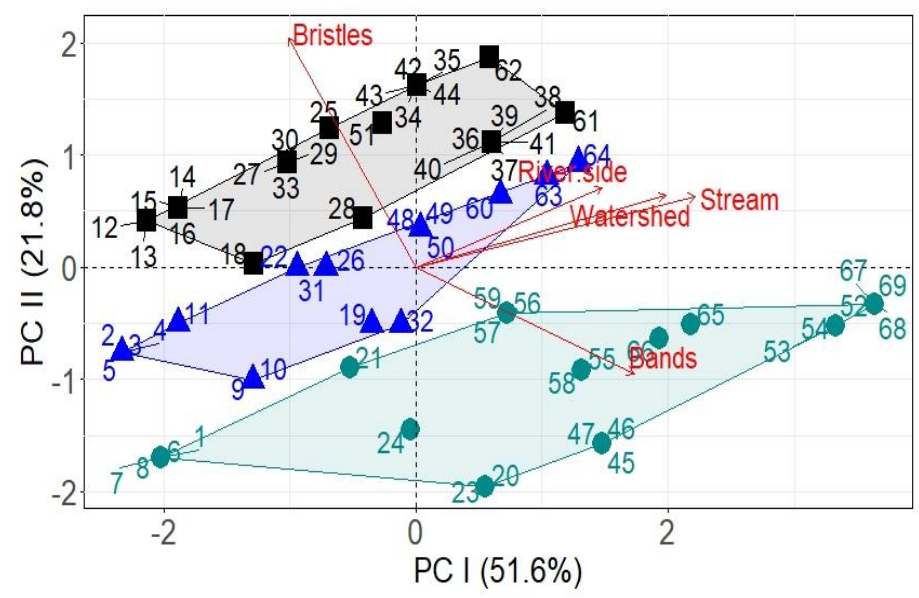

A. Bristle abundance $1 \oplus 2 \square 3$

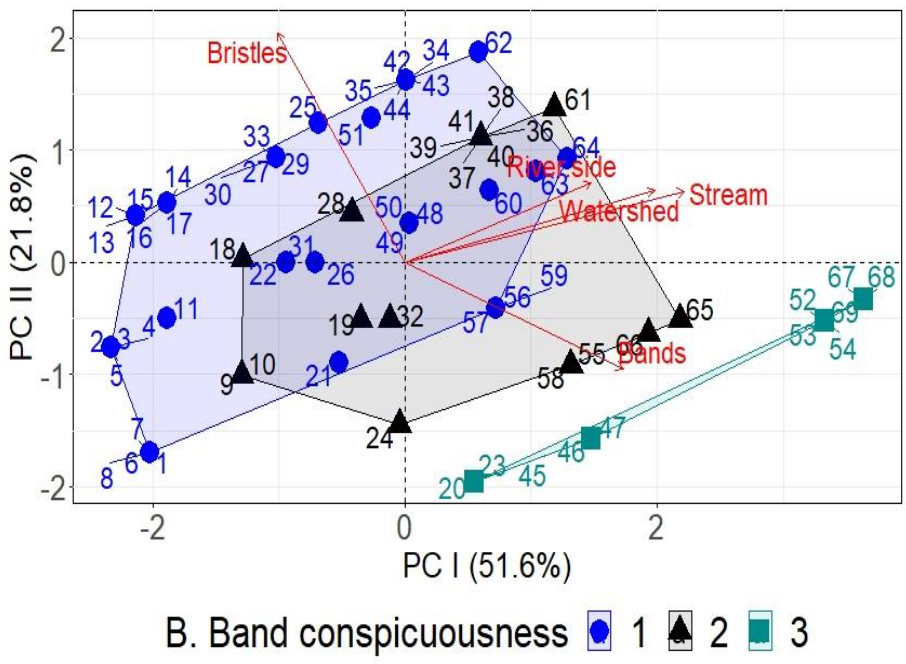

Figure 5. Principal components analysis (PC) of morphological and hydrological attributes of the locations were genetic samples were obtained: A) bristles and B) bands based on: UTM-east and UTM-north directional reference coordinates, and position in relation to river-side, and designated watersheds and adjacent riparian stream corridors. Sample locations correspond to the phylograms below, including: Bidden Cr. 1, Bidden Cr. 2, Bidden Cr. 3, Bidden Cr. 4, Bidden Cr. 5, Bidden Cr. 6, Bidden Cr. 7, Bidden Cr. 8, Big Cr. 9, Big Cr. 10, Big Cr. 11, Big Cr. 12, Big Cr. 13, Corral Cr. 14, Corral Cr. 15, Corral Cr. 16, Corral Cr. 17, Corral Cr. 18, Dyer Cr. 19, Dyer Cr. 20, Bell Cr. 21, Dyer Cr. 22, Dyer Cr. 23, Dyer Cr. 24, Hayfork Cr. 25, Hyampom Cr. 26, Hyampom Cr. 27, Hyampom Cr. 28, Hyampom Cr. 29, Hyampom Cr. 30, Hyampom Cr. 31, Hyampom Cr. 32, Hyampom Cr. 33, Little Swede Cr. 34, Little Swede Cr. 35, Little Swede Cr. 36, Little Swede Cr. 37, Little Swede Cr. 38, Little Swede Cr. 39, Little Swede Cr. 40, Little Swede Cr. 41, Little Swede Cr. 42, Little Swede Cr. 43, Little Swede Cr. 44, Fourmile Cr. 45, Fourmile Cr. 46, Fourmile Cr. 47, Olson Cr. 48, Olson Cr. 49, Olson Cr. 50, Olson Cr. 51, Rosaleno Cr. W-side Klamath River 52, Rosaleno Cr. W-side Klamath River 53, Rosaleno Cr. W-side Klamath River 54, South Fork Road. Hennessy Peak 55, South Fork Road. Hennessy Peak. 56, South Fork Road Hennessy Peak. 57, South Fork Road Hennessy Peak. 58, South Fork Road Hennessy Peak. 59, Sulphur Glade Cr. 60, Swede Cr. 61, Swede Cr. 62, Salyer 63, Grays Falls 64, Grays Falls 65, Salyer 66, Whitmore Cr. E-side Klamath River 67, Whitmore Cr. E-side Klamath River 69, Whitmore Cr. E-side Klamath River 69. 


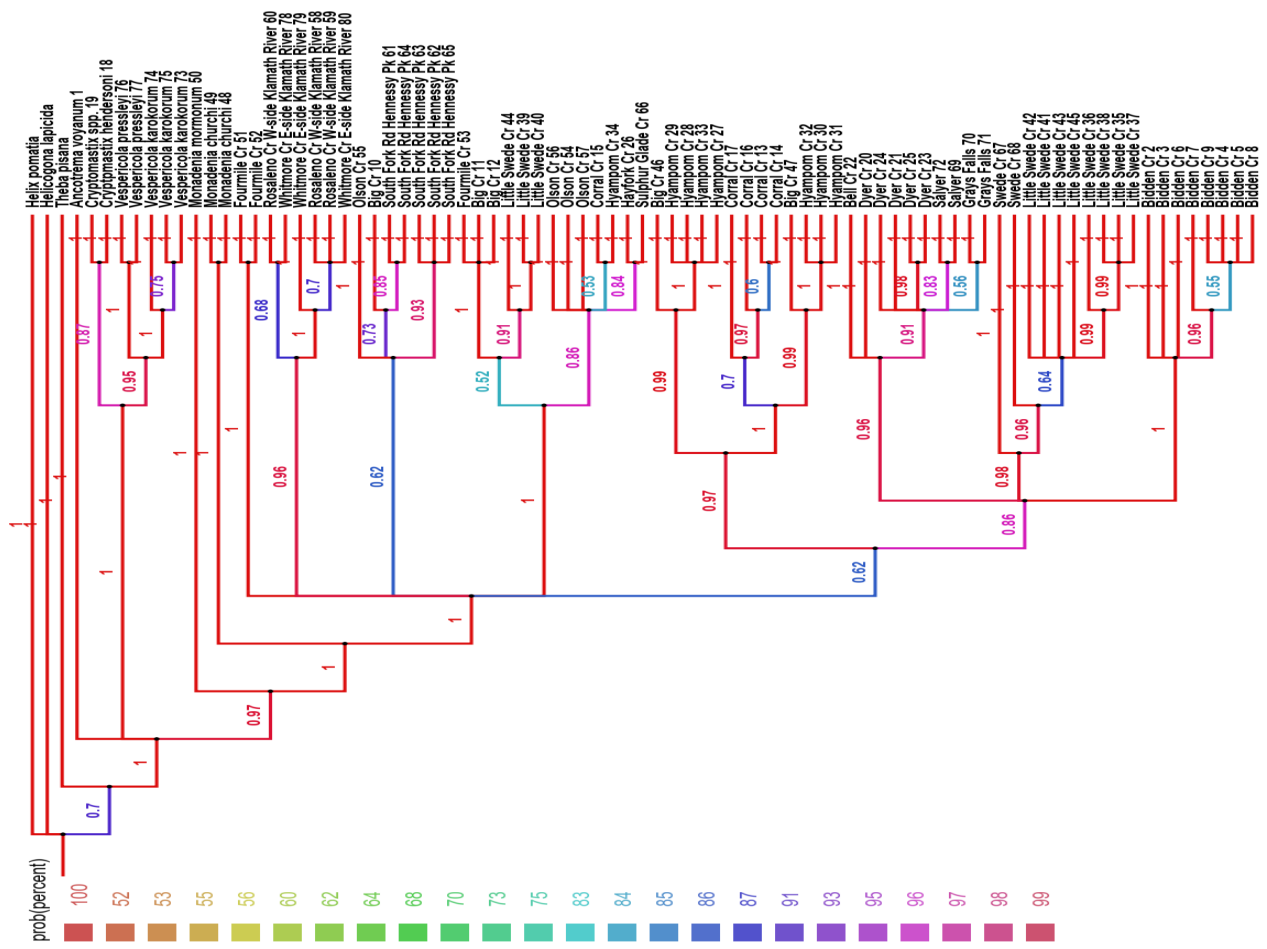

Figure 6. Phylogram generated by MrBayes Maximum Clade Credibility tree jointly calculating both distance and nucleotide substitution models constructed from DNA sequence data that best fit tree reconstructions. Clades, branches, and numbers are colored by posterior probabilities for well-supported clades.

and each clade shaded with green had $90.0 \%$ probability of being a species based on the bGMYC analysis (Table 4 ). Only clades that had $95.0 \%$ species probability were cartooned. Individual samples were colored to indicate that the analysis distinguished clades at the $95.0 \%$ probability level as distinct subclades (species or subspecies). This analysis provided evidence that the Redwood sideband, Yellow-based sideband, and Trinity bristle snail appear to be good species given that there was decent phylogenetic signal among their clades at $95 \%$ species probability even though the most recent taxonomic treatise considered each taxon a subspecies of the Redwood sideband (i.e., M. i. subcarinata, M. i. ochromphalus, and M. i. setosa; Roth and Sadeghian 2006).

Redwood sideband.-This species has a distribution extending from Northern California to central California including: Del Norte, Humboldt, Mendocino, Sonoma, Napa, Marin, Contra Costa, Alameda, Siskiyou, and Trinity counties (Roth and Sadeghian 2006). Results of the DNA analysis provided evidence that the Redwood sideband (A-clade) was the common ancestor of both the Yellow-based sideband (B-clade) and Trinity bristle snail (C-clade; Fig. 9). And that there was significant genetic differentiation within samples consistent with hydrology and geography along the northeast and southwest sides of the central mainstem of the Trinity River, northwest slope of the New River gorge, and eastside of the South Fork Trinity River corresponding to the Hyampom subclade, South Fork subclade, and Swede Creek subclade. 


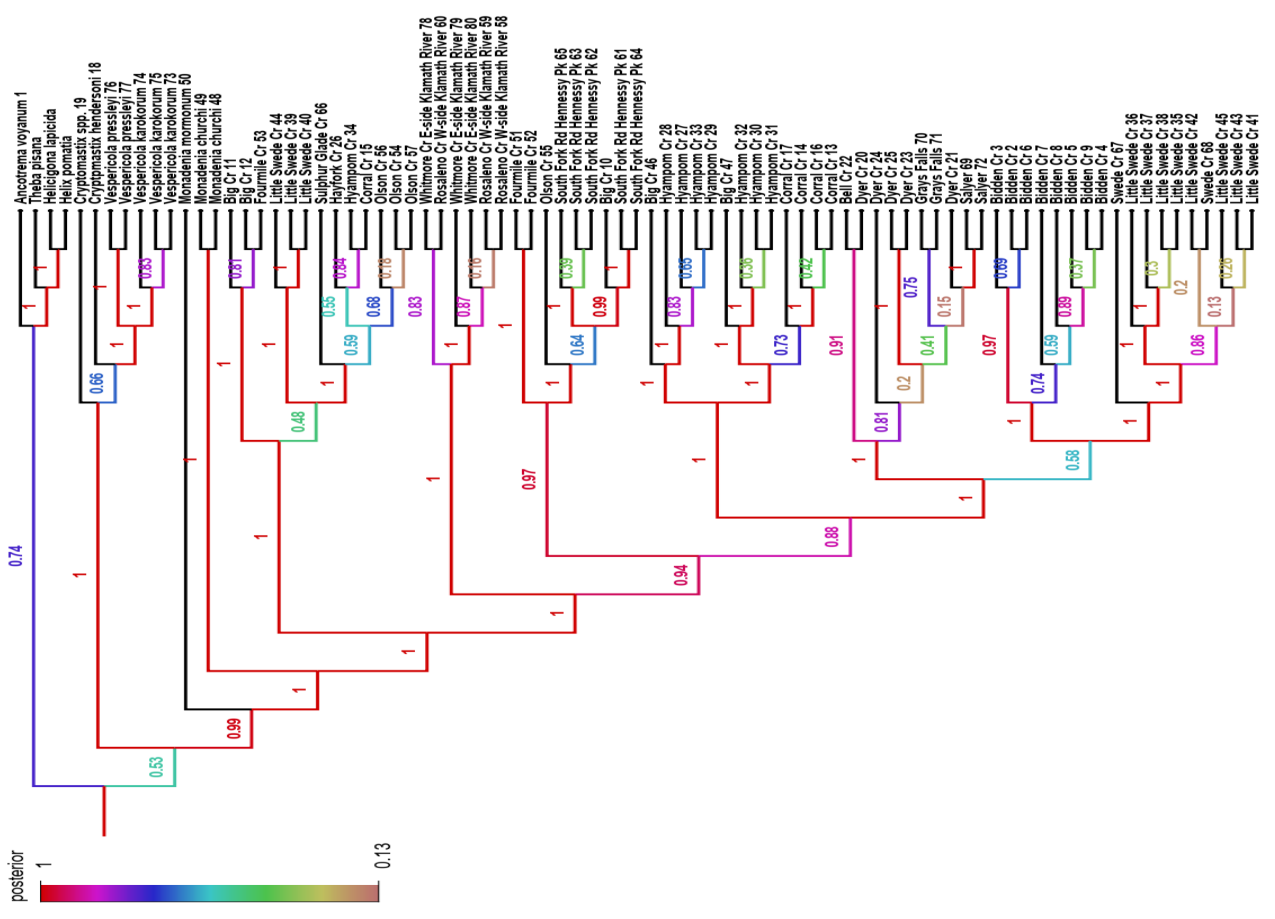

Figure 7. Tree generated by the Randomized Axelerated Maximum Likelihood (RAxML) Blackbox interface program using the General Time Reversible (GTR) nucleotide substitution model. Phylogram summarizes results of European outgroups and numbered genetic samples. Clades, branches, and numbers are colored by posterior probabilities for well-supported clades.

The Hyampom subclade of the Redwood sideband occurs within west-central Trinity County bounded by the central Trinity River, in the vicinity of Hayfork Creek, headwaters of South Fork Trinity River, and the eastern slope of South Fork Mountain (Hayfork, Hyampom, Corral, Olson, and Sulphur Glade creeks; Fig. 10b). The South Fork subclade includes areas within eastern Humboldt County and the west-side of the South Fork Trinity River (Big and Fourmile creeks). The Swede Creek subclade includes areas within Trinity County on the northeast-side of the central Trinity River (Swede and Little Swede creeks). Importantly, this taxon was geographically sympatric and co-occurred in the same ecological setting with the Trinity bristle snail at several locations throughout the greater Trinity Basin, which could have resulted in introgression. Because genetically and geographically distinct subclades of Redwood sideband were identified as syntopic with other similarly differentiated subclades within the Trinity bristle snail, these data are viewed as consistent with the degree of species-probability delineated by the BEAST consensus tree.

Yellow-based sideband.-This species has a distribution in Northern California that includes Del Norte, Humboldt, and Siskiyou counties. All DNA phylograms showed that the Yellow-based sideband (B-clade) and the Trinity bristle snail (C-clade) are sister-taxa derived from a common ancestor with the Redwood sideband. Nevertheless, all sister-taxa relationships within the genus Monadenia would need to be addressed for all species in a comprehensive molecular analysis to falsify this hypothesis. Within the B-clade there does 


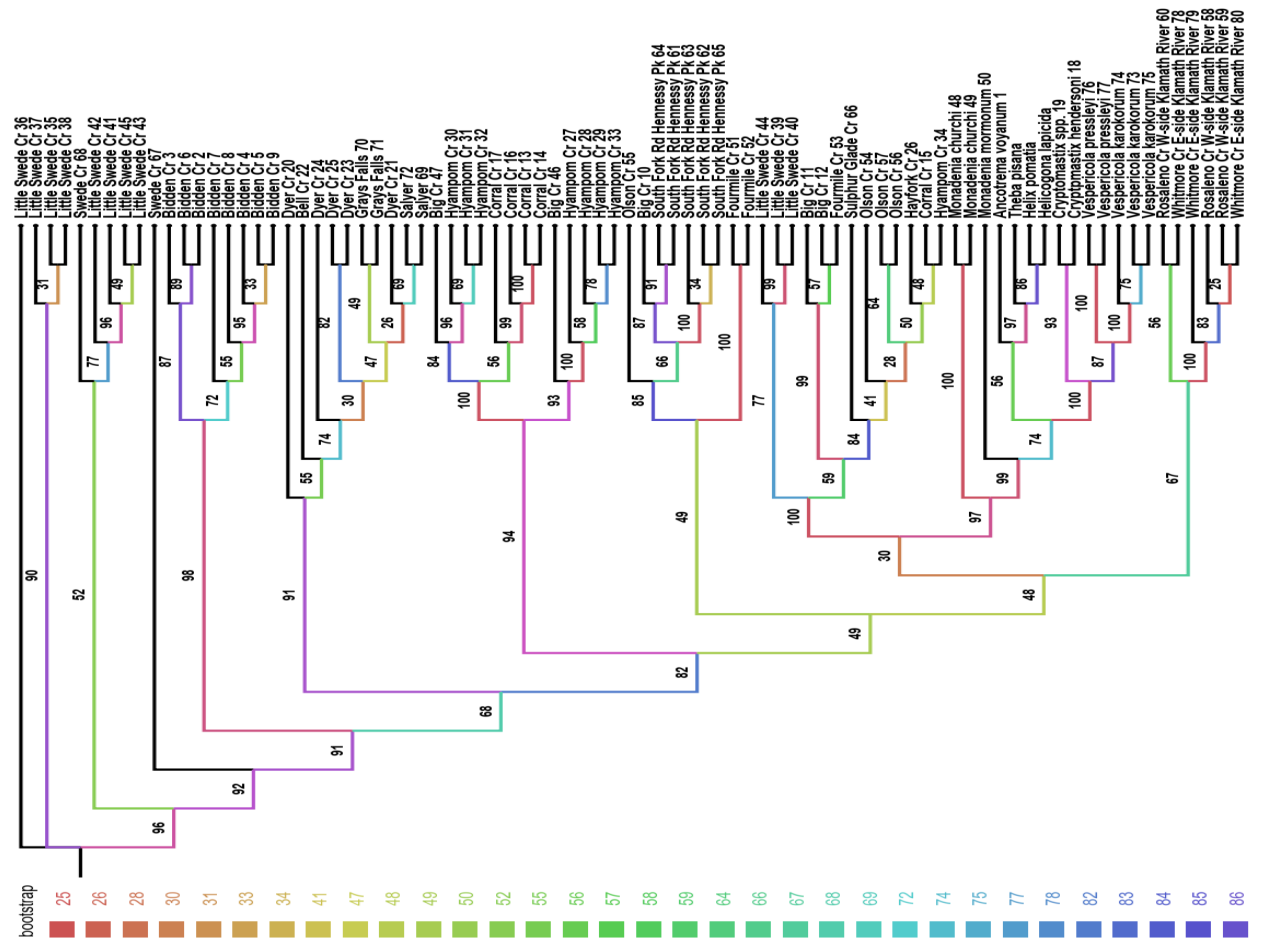

Figure 8. Phylogram generated by the Bayesian Coalescent Tree reconstructed from DNA sequenced data using the program BEAST summarizing genetic relationships among European outgroups and numbered genetic samples. Clades, branches, and numbers are colored by bootstrap percentages for well-supported clades.

not appear to be sufficient genetic divergence between subpopulations consistent with hydrology or geography to justify subspecies designation. Genetic samples were collected on adjacent but opposite sides of the Klamath River at Whitmore Creek and Rosaleno Creek that were within 4.0 kilometers $(2.5 \mathrm{mi}$.) of each other at the extreme northeast boundary of Humboldt County with Siskiyou County. Separation between these two locations appears recent such that the Klamath River at this geographic location has not historically functioned as a significant riverine or topographic barrier to gene flow between populations on opposite sides of this headwater reach in the Klamath River system.

Trinity bristle snail.-For the Trinity bristle snail all DNA phylograms identified a series of allopatric polytomous subclades within the C-clade. And bristles were present in many individuals representative of each subclade whether sparse or abundant, and irrespective of age (size). These subclades consisted of five rather well-defined genetic subunits exhibiting significant geographic variation characteristic of restricted gene-flow in relation to separation by riparian stream corridors and major river systems within the greater Trinity Basin (Fig. 8 and Fig. 9). 


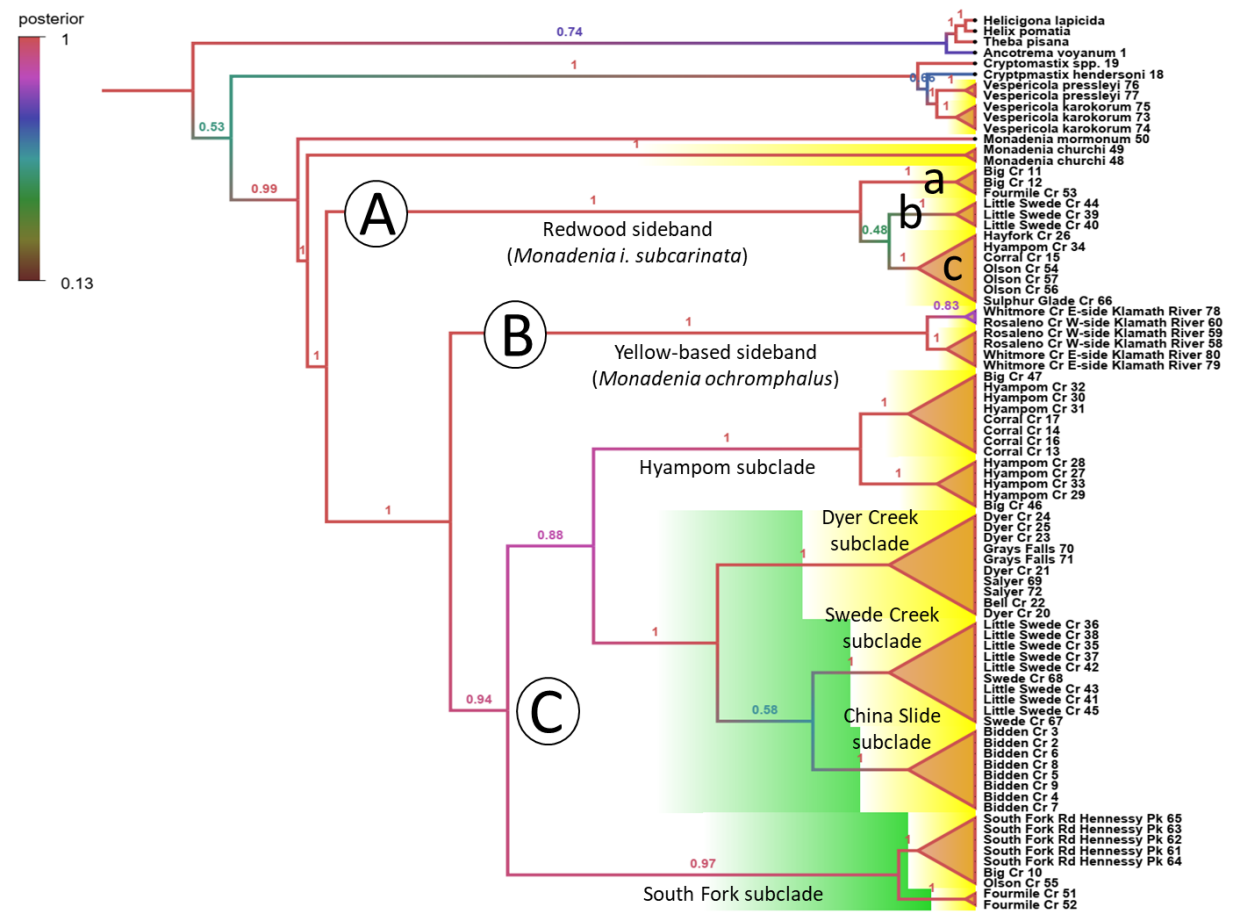

Figure 9. BEAST Consensus Tree with cartooned (triangled) clades summarizing genetic relationships among European outgroups and numbered genetic samples. Branches are colored by bootstrapping. Clades shaded yellow have $<95 \%$ probability of being a species and clades shaded green have $<90 \%$ probability of being a species. Only clades that had $<95 \%$ species probability were cartooned. Samples are colored to reflect that the analysis distinguishes clades at the $<95 \%$ probability level as distinct subclades (species or subspecies). For M. subcrinata subclades: $\mathrm{a}=$ South Fork subclade, $\mathrm{b}=$ Swede Creek subclade, $\mathrm{c}=$ Hyampom subclade. Branches are colored by posterior probabilities for well-supported clades.

The China Slide subclade at Bidden Creek was located downriver on the opposite and west-side of the central mainstem Trinity River in the vicinity of the China Slide ${ }^{14}$. This subclade represents a homogenous site-specific genetic sample that is the "sister-taxon" to the Swede Creek subclade. The Dryer Creek subclade occurs within the northeast side of the central mainstem Trinity River and on the northwest slope of the New River gorge. It is separated from all other subclades by two major river systems from the south and east. Here there was consistent genetic separation between Hawkins Creek and Bell Creek riparian corridors, and genetic samples adjacent to the Trinity River at Grays Falls and Salyer. Genetic subunits that made up the Hyampom subclade (Hyampom Cr., Corral Cr., Big Cr.) were somewhat intermingled. Although Corral Creek samples grouped together in every phylogram, there were no apparent major geographic or hydrological barriers to geneflow, a similar pattern of genetic variation was also observed in the Redwood sideband from the Hyampom and Corral creek areas.

\footnotetext{
${ }^{14}$ Bidden Creek along Highway 299 near the China Slide and Burnt Ranch should not be confused with a different Bidden Creek that is a tributary of Corral Creek between Big Bar and Hyampom in Trinity County, which was the population monitoring site for the Roth and Pressley (1986) study.
} 
Table 4. Hypothesized new species clades and subclades based on results of the genetic analyses using BEAST consensus tree, posterior probability scores, and with cartooned (triangled) bGMYC scores to arrive at a hypothesized taxonomic classification and subclade designation based on Trinity County geography and riverine barriers to gene flow within each clade based on results of the present study.

\begin{tabular}{|c|c|c|c|}
\hline Species clade & $\begin{array}{l}\text { Posterior probability } \\
\text { score }(\%)\end{array}$ & bGMYC score & Taxon (species/subclade) \\
\hline \multirow[t]{4}{*}{ A-clade } & 1.00 & & $\begin{array}{l}\text { Redwood sideband (Monadenia infu- } \\
\text { mata) (= M. i. subcarinata) }\end{array}$ \\
\hline & 1.00 & 0.95 & $\begin{array}{l}\text { (a) Hyampom subclade: W-side central } \\
\text { Trinity River, NE-side South Fork Trin- } \\
\text { ity River, lower Hayfork Creek. }\end{array}$ \\
\hline & 1.00 & 0.95 & $\begin{array}{l}\text { (b) South Fork subclade: W-side South } \\
\text { Fork Trinity River and South Fork } \\
\text { Mountain }\end{array}$ \\
\hline & 1.00 & 0.95 & $\begin{array}{l}\text { (c) Swede Creek subclade: NE-side } \\
\text { central Trinity River }\end{array}$ \\
\hline B-clade & 1.00 & & $\begin{array}{l}\text { Yellow-based sideband (Monadenia } \\
\text { ochromphalus) }\end{array}$ \\
\hline \multirow[t]{6}{*}{ C-clade } & 0.94 & & Trinity bristle snail (Monadenia setosa) \\
\hline & 1.00 & 0.95 & $\begin{array}{l}\text { (a) China slide subclade: Trinity Co., } \\
\text { W-side central mainstem Trinity River, } \\
\text { vicinity of China Slide }\end{array}$ \\
\hline & 1.00 & 0.95 & $\begin{array}{l}\text { (b) Dyer Creek subclade: Trinity Co., } \\
\text { NE-side central mainstem Trinity River, } \\
\text { NW-side New River gorge }\end{array}$ \\
\hline & 1.00 & 0.95 & $\begin{array}{l}\text { (c) Hyampom subclade: Trinity, W-side } \\
\text { central mainstem Trinity River, N-side } \\
\text { central mainstem South Fork Trinity } \\
\text { River, area surrounding Hyampom, Cor- } \\
\text { ral, and Big creeks }\end{array}$ \\
\hline & 1.00 & 0.95 & $\begin{array}{l}\text { South Fork subclade: Trinity and Hum- } \\
\text { boldt Cos., W-side mainstem South Fork } \\
\text { Trinity River, Friday Ridge Rd., Olson } \\
\text { Creek Watershed }\end{array}$ \\
\hline & 1.00 & 0.95 & $\begin{array}{l}\text { (d) Swede Creek subclade: Trinity Co., } \\
\text { NE-side central mainstem Trinity River, } \\
\text { Type Locality at Swede Creek. }\end{array}$ \\
\hline
\end{tabular}

The South Fork subclade appeared to show significant geographic variation between the: 1) westside of the mainstem South Fork Trinity River before draining into the lower Trinity River near Friday Ridge Road, Humboldt County; and 2) westside of the South Fork Trinity River. Although within the Ammon Creek watershed there were two samples that were immediately adjacent to the eastside of the South Fork Trinity River and one within the Olson Creek watershed between the South Fork Trinity River and Hayfork Creek. For the most part, this pattern of genetic variation appears related to restricted gene-flow combined with both isolation by geographic distance and riverine barriers. Notably, the two specimens 


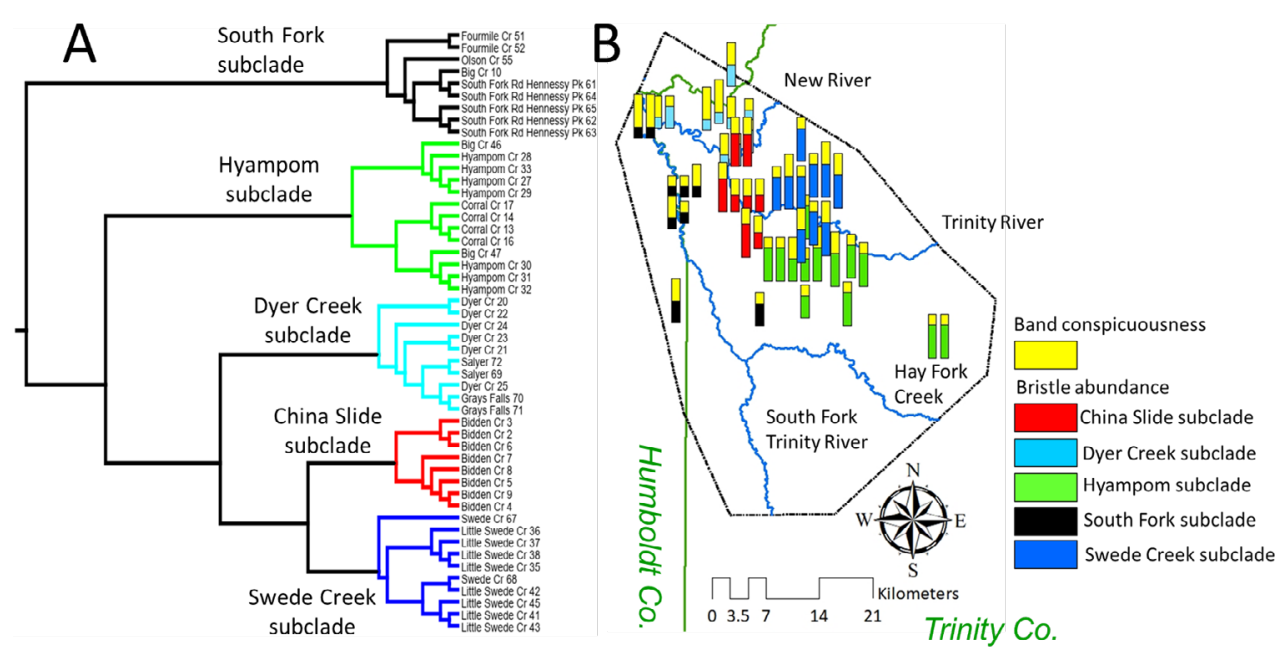

Figure 10. A) Reduced species phylogram derived from DNA sequence data reconstructed by use of the Bayesian Coalescent Tree using the program BEAST. Subclades in the distribution map are color coded to match samples in the phylogram. B) Map of the distribution of various subclades within the C-clade of the Trinity bristle snail ( $M$. setosa) showing the comparative abundance of bristles and conspicuousness of bands for each subclade throughout the current range of the species. Paired bar graphs represent ranks $(1-3)$ that each snail had for bristle abundance (non-yellow bars) or band conspicuousness (yellow bars); no snail had a 3:3 ranking of bristles to bands.

from Fourmile Creek (\#51 and \#52) found on the westside edge of the South Fork Trinity River were clearly differentiated genetically from the co-occurring Redwood sideband (\#53). The Swede Creek subclade represents the type locality for the species. Samples were obtained from both Swede Creek and Little Swede Creek, within the Italian Creek watershed. These drainages represent two adjacent but separate streams at their headwaters prior to merging downstream as a minor tributary to the central mainstem of the Trinity River. There was no significant genetic separation between these samples that could be attributed to geography (Fig. 8 and Fig. 9).

Figure 10 illustrates the biogeographic relationships among subclades within the $\mathrm{C}$ clade of the Trinity Bristle species complex in relation to: 1) the abundance of bristles; 2) conspicuousness of bands; 3) distribution of major river systems flowing from the southeast to the northwest; and 4) the DNA-derived phylogram generated from the Bayesian Coalescent tree. Within each subclade the genetic samples have rather uniform abundance and conspicuousness of bristles and bands, respectively as shown by individual bar graphs. Yet the proportion of abundance and conspicuousness of these two morphological variables become somewhat intermixed in the extreme northwest section of the geographic range, even though strong genetic separation is indicted by the phylogeny.

\section{Parsimony Character State Reconstructions}

Parsimony character state reconstructions within the $\mathrm{C}$-clade showed that the strongest phylogenetic signal was associated with: 1) adjacent riparian stream corridors, 2) watershed designations, and 3) the geographic location compared to a particular side of the Trinity River, South Fork of the Trinity River, and the New River gorge (Fig. 11A, 11B, and 11C). In most 
all subclades, DNA samples tied genetically to their unique hydrologic and topographic landscape. Similarly, most subclades had their most divergent genetic samples associated with geographic separation between these major riverine systems, suggesting isolation and a resulting lack of gene flow among allopatric populations. This pattern appeared particularly evident for downriver mainstem segments of the Trinity River and South Fork Trinity River as opposed to less flow inundated upriver reaches of the South Fork Trinity and its lesser Hayfork Creek tributary.

In contrast, although comparative abundance of bristles, and to a lesser extent the conspicuousness of bands, provided some additional phylogenetic signal as most taxa in clades with $<95 \%$ probability of being a species or subspecies had shell exteriors consisting of distinct bristles and slightly conspicuous bands as adults (Fig. 12A and 11B). Presence and abundance of bristles on the surface of adult shells within the C-clade was found to be highly variable. This finding in no way negates the problem of sample size in the genetic analysis but needs to be reinforced with much larger samples of adult specimens throughout the range of the species, particularly if a multivariate morphometric assessment of adult snails is to be successful. However, within subclades of the Trinity bristle snail bristle abundance was found to provide little in the way of phylogenetic information.

For example, although bristles were present in representatives of each subclade this was highly variable among individual snails sampled at the same location consistent with the analysis presented in Figure 10. Samples of adult Trinity bristle snails from the type locality (Swede Cr. subclade) characteristically had abundant and conspicuous bristles, whereas specimens from its sister subclade (China Slide subclade) downstream and across the central mainstem of the Trinity River had no bristles or were very sparsely bristled. Similarly, specimens from the Hyampom subclade had a high degree of samples with abundant bristles but a few snails were sparsely bristled. Within each subclade presence of sparse bristles may be a function of several factors: 1) age variation (size), 2) degree of wear to the shell surface, 3) degree of isolation, 4) genetic drift and founder effects, 5) local areas effects (selection), or 6) simply sampling error (Cain and Currey 1963; Davison and Clarke 2000; Millstein 2008, 2009).

As in bristle abundance, parsimony character state reconstructions for riparian stream corridors versus conspicuousness of banding on the surface of shells in adult specimens also appeared highly variable and provided little in the way of phylogenetic information when compared to the DNA analyses. Generally, traditional phenotypic descriptions of the banding patterns in a species are associated with large adult specimens in which presence, color, degree, and the patterning of bands are well developed, if bands are present at all. Similarly, the majority of large adult specimens with or without bristles examined here were dull in coloration, and even the largest bands around the body whorl at the edge of the shell were not well pronounced, wide, bright, or highly conspicuous. Instead, the quality of "conspicuousness" of bands was highly variable throughout the C-clade, with slightly conspicuous banding patterns being most common and highly conspicuous banding patterns uncommon.

\section{DISCUSSION}

\section{Morphology}

The Trinity bristle snail was originally described based on morphological criteria from specimens collected at the type locality along Swede Creek $\left(40.793^{\circ} \mathrm{N}, 123.355^{\circ}\right.$ 


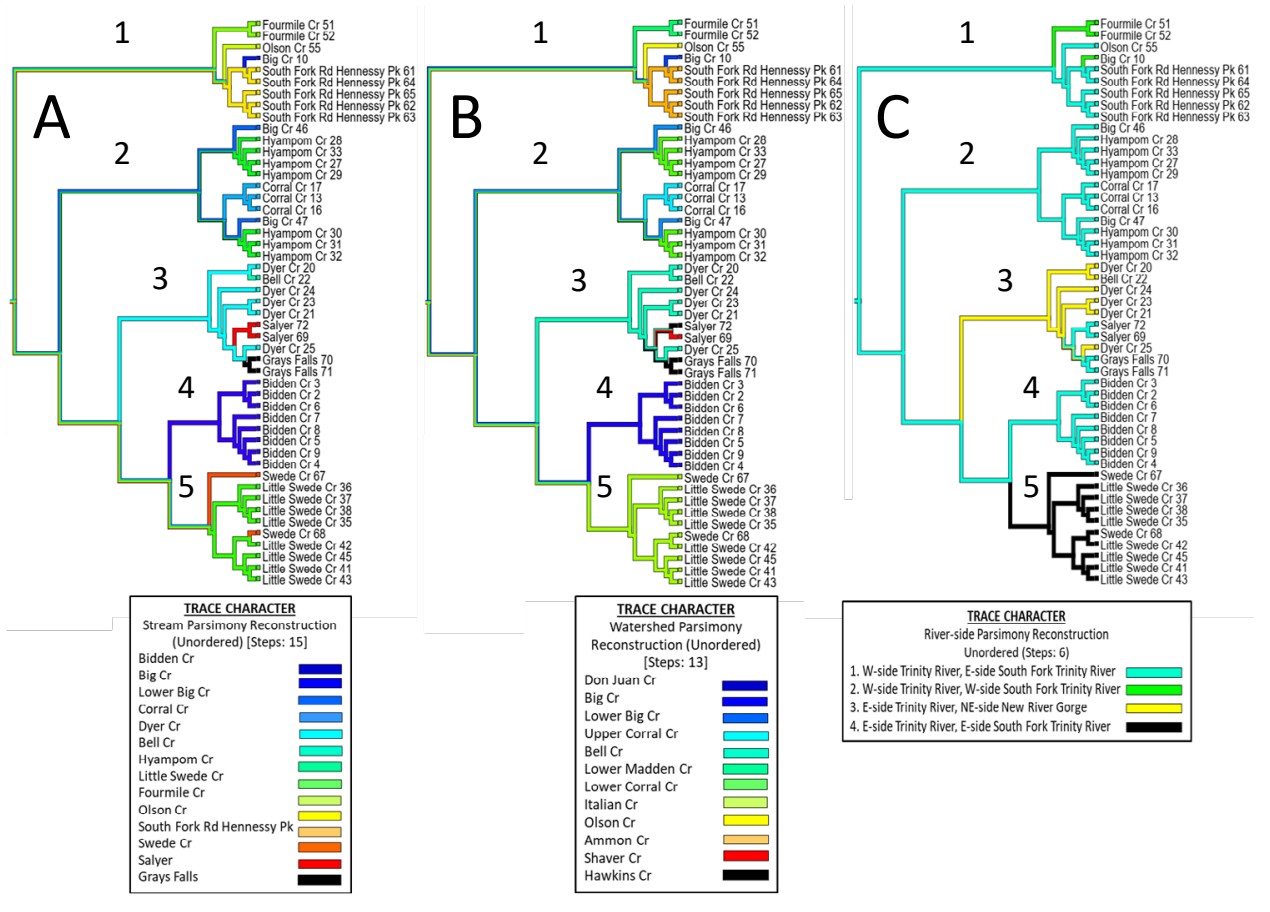

Figure 11. Ranked hydrologic parsimony character state reconstructions applied to genetic samples used in the BEAST consensus tree: A) riparian stream corridor, B) watershed, and C) river-side. Subclades within the Trinity bristle snail ( $M$. setos $a$ ) complex: 1 = South Fork subclade, $2=$ Hyampom Creek subclade, $3=$ Dyer Creek subclade, $4=$ China Slide subclade, and $5=$ Swede Creek subclade.

W), northeast of the Trinity River and adjacent to Highway 299, Trinity County, California (Talmadge 1952). At that time Swede Creek was the only locality for the species known to Talmadge, who did not specify where along its reach collections were made. Traditionally, differences between the Trinity bristle snail and other species within the genus Monadenia characteristically involved comparatively minor differences in shape, banding pattern, and proportion of the several organs of the reproductive system. For example, the shape of the mucus gland and its duct in the Trinity bristle snail appears more like that of the Redwood sideband than that of the Pacific sideband (Roth and Eng 1980). Conformation of such relationships by additional dissections and quantified morphological criteria would be consistent with results of the molecular data presented here and by Cordero and Lindberg (2002), which grouped the Trinity bristle snail into a clade with the Redwood sideband. Complicating the morphological scenario further was the observation that traditional taxa within the genus Monadenia (M. setosa, M. infumata, M. fidelis subcarinata, M. f. klamathica, and M.f. ochromphalus), which formerly appeared distinct based on the original morphological criteria, were found to be less than definitive based upon subsequent re-examination as a function of more extensive sampling (Roth 2002; Roth and Sadeghian 2006).

Evidence presented here shows that: 1) the Redwood sideband (A-clade) is the common ancestor of both the Yellow-based sideband and Trinity bristle snail; and 2) a sister-group 

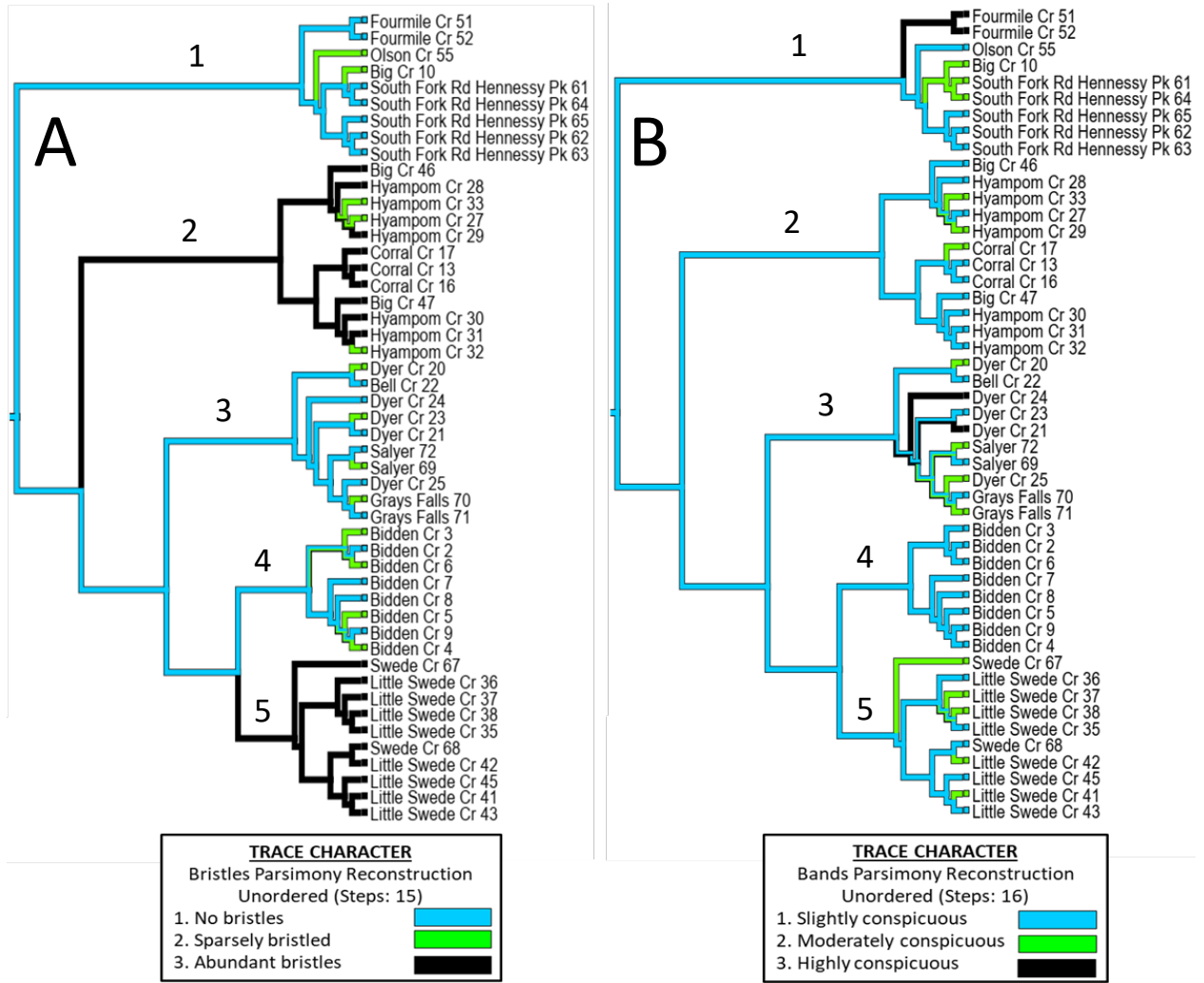

Figure 12. Ranked morphological parsimony character state reconstructions applied to genetic samples based on: A) presence or absence of bristles on the surface of the shell and B) conspicuous of banding on the surface of the shell. Subclades within the Trinity bristle snail $(M$. setos $a)$ complex: $1=$ South Fork subclade. $2=$ Hyampom Creek subclade, 3 = Dyer Creek subclade, $4=$ China Slide subclade, and $5=$ Swede Creek subclade.

relationship exists between the Yellow-based sideband (B-clade) and the Trinity bristle snail lineage (C-clade). Yet the existing descriptive morphological criteria provides negligible insight into the geographic and evolutionary relationships among species, subclades, or subspecies. Discussions regarding use of shell morphology in phylogenetic analyses (Uit de Weerd et al. 2004; Smith and Hendricks 2013; Miller 2016), although informative at lower taxonomic resolutions, generally are not particularly useful in accurate delimitation of cryptic lineages. This is because of the high responsiveness of shell structure and banding pattern to environmental factors and similarity in local and regional adaptations in terrestrial gastropods (Goodfriend 1986; Fiorentino et al. 2008; Stankowski 2011; Cameron et al. 2013; Razkin et al. 2017).

As noted by Gladstone et al. (2019) molecular studies have recently led to the detection of many cryptic species complexes within morphologically ambiguous taxa that have previously been undescribed, the primary motivation for the Cordero and Lindberg (2002) study. Morphological assessment of taxa within the genus Monadenia would benefit greatly by use of genetic criteria, geometric morphometrics, and traditional morphometrics in combination with methodology such as permutational MANOVA for use in discriminate 
function study designs. Such analyses are particularly important were researchers are unable to find characters that consistently differentiate one taxon from another (Anderson 2017). Organisms such as land snails are at a particularly higher risk of species misidentification and misinterpretation, in that gastropod systematics have traditionally been based almost entirely on external shell morphology (Gladstone et a. 2019).

For example, patterns of variation in shell morphology vary locally and among regions, and selection may be mediated by climate or predation (Cain and Currey 1963; Cook, 1998; Silvertown et al., 2011). Currently, there has been no published comprehensive univariate, multivariate, or cladistics analysis of shell or soft anatomy comparisons among traditional species within the genus Monadenia, or geographically differentiated subspecies within the genus. Also, there are no published companion keys to species, clades, subclades, or subspecies based on morphological criteria of any kind consistent with current taxonomic treatments, even though extensive new taxonomic classifications continue to be published. What is needed are genetic studies in conjunction with quantitative multivariate morphological analyses. These investigations should focus on all species and subspecies within the genus Monadenia as per the most recent taxonomy using a comparative approach combined with geographic information as part of the process of developing usable keys to taxa for the purpose of management and conservation.

\section{Sample Size and Distribution}

Importantly, Cordero and Lindberg (2002) showed that their specimen \#20 labeled as a Trinity bristle snail sampled at Hayfork Creek in southwest Trinity County did not group with: 1) their C-group consisting exclusively of the Redwood sideband except for one specimen (\#19) labeled as a Trinity bristle snail from the type locality at Swede Creek; or 2) their D-group consisting exclusively of the Yellow-based sideband from Siskiyou County (Appendix I). Instead, their molecular data showed that the Trinity bristle snail from Hayfork Creek was the most divergent of all samples assayed in their "bristle clade" (B-group). However, no explanation was offered for this apparent "anomaly," even though specimen \#19 was assigned to their C-group along with all other samples of the Redwood sideband from Trinity and Humboldt counties.

Importantly, based on the DNA data and more extensive sampling presented here, the relationships depicted by the Cordero and Lindberg (2002) phylogram would appear to indicate sympatry between the Trinity bristle snail and the Redwood sideband at the type locality for the Trinity bristle snail (Appendix I). For example, their specimen sampled at Swede Creek may not have been a Trinity bristle snail, but a morphologically cryptic Redwood sideband as reflected in their phylogram. Given the very small geographic area covered and the indication that all four samples of the Redwood sideband were obtained from the same location in adjacent Humboldt County, ${ }^{15}$ well within the range of this species in adjacent Trinity County, it is not surprising that the taxonomic boundaries of species, subspecies, and population-level taxonomy described in their account appeared "fuzzy" and largely unresolved.

\footnotetext{
${ }^{15}$ In the final report to the Roseburg Bureau of Land Management in Oregon, Cordero and Lindberg (2002) indicate that the two specimens of the Pacific sideband (= Redwood sideband); \#43 and \#44) were collected in Trinity County (T4N, R5E, S18 1/4SE). However, these coordinates indicate that Section 18 lies within Humboldt County, which would place these samples within the same cluster of rock pits (Lower Trinity River Rock Pits, Six Rivers National Forest) as all other samples of this taxon sampled from Humboldt County and that none of their samples were from Trinity County.
} 
Inclusive with genetic and modern morphometric analyses are the effects of sample size and sampling distribution that are critical in evaluating the: 1) phylogenetic and biogeographic relationships among taxa, 2) taxonomic classifications, and 3) status and listing process required in the evaluation of rare and endemic species. As noted by Phillips et al. (2019), recommended sample sizes (5 - 10 individuals) currently in place likely are not sufficient because species abundance is often skewed geographically and ecologically. And sampling of $\geq 25$ individuals may be necessary for some species exhibiting widespread distribution patterns within topographically diverse landscapes (Becker et al, 2011; Steinke and Hanner 2011). Noteworthy is the very limited comparative DNA sequence analysis of the genus Monadenia that resulted in the Trinity bristle snail taxonomically subsumed within the Redwood sideband lineage. This is because the analysis did not include a reassessment of Trinity bristle snails from throughout its known topographically and hydrologically diverse geographic range as only two specimens were assayed (Cordero and Lindberg 2002). Multiple samples of Trinity bristle snails at each location were not collected even though there was compelling evidence to suggest the possibility of the co-occurrence of morphologically cryptic species (Roth and Pressley 1986). Nevertheless, Cordero and Lindberg (2002) concluded that species in their "bristled" B-group correlated with the existence of setae on the shells at some time during ontogeny, which equated to five polytomous subclades (infumata, setosa, subcarinata, klamathica, and ochromphalus; Appendix I). Given the huge geographic area covered and the small sample sizes evaluated, it is not possible to assess any population genetic aspect of geographic variation within the B-group. And no quantitative or semi-quantitative distinction was made about the distribution, geographic variation, or abundance of setae on the shell (sparse, abundant, dense).

In contrast, results reported here suggest a pattern of area effects consisting of a general southeast-to-northwest distribution in the abundance of bristles in the direction of the prevailing flow of the mainstem Trinity River, South Fork of the Trinity River, and Hayfork Creek, which bisect this section of the Trinity Basin. Abundantly bristled individuals were generally found to the southeast whereas more sparsely bristled individuals were generally found in the northwest in relation to existing riverine corridors. The opposite trend was apparent in the conspicuousness of bands. These patterns appeared to reflect rather shallow clines among genetic samples differing in bristle and shell banding morph frequencies in both the Trinity bristle snail and the Redwood sideband. Yet the subclades in both species were abruptly differentiated by genetic, hydrologic, and geographic discontinuities. Importantly, parsimony character state reconstructions that superimposed bristle and band data onto the BEAST consensus tree clearly indicated that presence of bristles and conspicuousness of bands was widespread among genetic samples, but neither attribute appeared to function as a definitive character for any species or subclade that possessed them.

\section{Species and Topotype}

Species are generally defined as populations that are reproductively isolated, or exclusive groups of organisms in which species boundaries in sympatry are maintained by intrinsic barriers to gene exchange (Harrison and Larson 2014). Unfortunately, morphological methods provide virtually no definitive quantitative insight as to the extent of gene flow, genetic intergradation (Mayr 1969), or the extent to which focal taxa differ phylogenetically from one another. The assumption that only small samples $(\leq 2)$ are needed from a "species population" to assess phylogenetic affinities, typical of modern genetic analyses 
is an exaggeration prone to sampling error. This situation is particularly challenging where morphologically cryptic species co-occur and there is a lack definitive morphological characteristics to facilitate positive identification, particularly under field conditions. For example, traditionally a "topotype" in taxonomy is a specimen found at the type locality of a species to which it is thought to belong but is not necessarily of that type series. The concept of the topotype and the need to obtain adequate sample sizes for both genetic and quantitative morphological analyses is important and potentially problematic. Not only is this material required for reassessing the validity of traditionally named taxa, refinement of species descriptions with multiple datasets, and taxonomic classifications, but given that there may be syntopic morphologically cryptic species co-occurring at the type locality, not only is it important to sample from the topotype, but it is critical that samples are actually the species of interest.

\section{Intergradation and Hybridization}

The South Fork clade is significant because it is an area (Don Juan Cr., Cedar Flat, and McDonald Cr. above Burnt Ranch) where Roth and Pressley (1986) found an unknown number of snails with a "partially matte base and light scattering of bristles on the shell," which they interpreted as evidence of a distinct but narrow zone of secondary contact and hybridization between the Pacific sideband (= Redwood sideband) and the Trinity bristle snail. These authors also suggested that because these shell and bristle characteristics were similarly observed by USFS personnel at Clark, Hyampom, and Corral creeks, that this might represent a southern extension of the hybrid zone in and around the Burnt Ranch area. They further suggested that this "narrow zone of apparent intergradation along the western margin of the range of the Trinity bristle snail indicates that genetic isolation from the Pacific sideband (= Redwood sideband) is not complete."

However, there are no published data in support of this hypothesis that would incorporate: 1) evidence of an exchange of genes between formerly allopatric species demonstrating they geographically reunited by natural introgressive hybridization, or 2) evidence of backcrossing with parental species at some time in the past or presently. Instead, the analysis of geographic variation in bristle abundance (and band conspicuousness) presented here found a predominately southeast-to-northwest decrease in bristle abundance coincidental with the direction of flow of the Trinity and South Fork Trinity Rivers, which was evident in both samples of the Trinity bristle snail and the Redwood sideband. This trend suggests a subtle "cline" in bristle abundance in the area described by Roth and Pressley (1986), where species populations likely are responding phenotypically to similar ecological conditions in syntopy. The historical and current literature is replete with quantitative evidence of examples of phenotypic responses to area effects in Cepaea nemoralis and other terrestrial gastropod species (Cain and Currey 1963; Jones et al. 1980; Cook, 1998; Davison and Clarke 2000; Ożgo and Kinnison 2008; Silvertown et al. 2011). Similarly, DNA derived phylograms showed a lack of intermediate subunits intermingled within subclades of each species in all zones of contact (South Fork, Swede Cr., and Hyampom subclades). Instead, distinct genetic subunits tied to hydrologic and geographic discontinuities in the landscape were found in both species. Viewed collectively these data would appear to contradict the concept of genetic intergradation between the Trinity bristle snail and the Redwood sideband where they co-occur given the available evidence. 
Minimal sampling detracts from the investigator's ability to address questions and estimates of the potential for gene flow and hybridization among taxa or relic populations. This situation applies to estimates of gene flow and assessment of the possibility of genetic hybrids between subclades of the Trinity bristle snail, and between this taxon and other large forest-dwelling gastropods that it may be sympatric with. Expanded analyses of nuclear genes and tracing of haplotypes would likely be required to document if hybridization has occurred between different taxa in the forms that lack the majority consensus bristle type or some other morphological criteria using both pure forms and potential intermediates in potential zones of contact. This requirement applies to estimates of gene flow and assessment of the possibility of genetic hybrids between taxa at any level among subclades of the Trinity bristle snail clade. Yet given that geographic sympatry and ecological syntopy between the Redwood sideband and several subclades within the Trinity bristle snail complex, including the type locality for the Trinity bristle snail, it would appear that these genetic units are conservatively at the subspecies level of differentiation, which in large measure is concordant with geographically disjunct riparian stream corridors and riverine systems, as shown in the BEAST coalescent tree (Fig. 7). Taken together, these data suggest further that the Trinity bristle snail is in fact a valid species as originally described by Talmadge (1952).

\section{Biogeographic Implications}

Phylogenetic affinities among subclades within the Trinity bristle snail complex and closely related taxa appear largely concordant with mesic hydrological relationships superimposed onto the geological and topological structure of the central Trinity Basin. This observation reinforces the hypothesis that lack of gene flow between disconnected stream and river basins, in concert with topography and past (Pleistocene) geologic history, has contributed to allopatric patterns of differentiation in taxa and relictual populations of large terrestrial forest-dwelling gastropods in the greater Trinity Basin of northern of California. Anecdotal to this hypothesis is the observation by Talmadge (1960) of the temporary occurrence of the Trinity bristle snails "twenty miles downstream" of Swede Creek where snails were presumably carried on flood flotsam drifting in the mainstem Trinity River, but this dispersal "propagule" apparently lasted only one year, as no other specimens were found or reported in follow-on surveys of the site (Roth 1978). This dispersal distance is within approximately 2 miles from the confluence of the Trinity River and the South Fork of the Trinity River near the town of Salyer and Grays Falls. According to Roth (1978), Talmadge also stated that river-born migrant Trinity bristle snails "went ashore" at Hawkins Bar on the flats of the floodplain of the Trinity River during the flood of 1964 but they did not persist past 1966. Hawkins Bar (SW-side of the Trinity River) is approximately $16.1 \mathrm{~km}$ (10 mi) by river from the confluence of the Trinity River with the South Fork Trinity River.

Similarly, although the samples from Grays Falls and Salyer were obtained close to the Trinity River, they were on opposite sides of the mainstem from upslope samples at Dyer Creek and Bell Creek. As indicated by the MrBayes maximum-credibility tree (Fig. 5A), the Dyer-Bell creek samples may have been the original genetic source (common ancestor) of the Grays Falls and Salyer (Trinity River) samples. Thus, this may be another example of downslope drift combined with cross-river colonization down river. The possibility that Trinity bristle snails and terrestrial gastropods in general are known to occasionally drift ashore downstream by way of riverine dispersal in currents of river systems suggests that dispersal and gene flow may be limited but ongoing periodically in conjunction with both 
the northeast and southwest sides of the mainstems of the Trinity River, New River gorge, South Fork Trinity River, and to a lesser extent the Hayfork Creek drainage, which conveys far less volume of water compared to mainstem flows.

For example, given the accumulated effects of: 1) larger, deeper, and swifter flows, and 2) greater erosion of riverbanks and floodplains toward the mouth of rivers, each riverine system would appear to be significantly more effective as a physical barrier to over-water dispersal the further downstream compared to upstream and headwater riverscapes. Passive riverine dispersal seems far more probable in association with tributary streams of the Hyampom subclade at Hayfork Creek and Corral Creek, and the head waters of the South Fork Trinity River in combination with the lack of other strong topographic barriers. This possibility would suggest that riverine dispersal of terrestrial gastropods goes from greater to lesser probabilities along a southeast-to-northwest corridor across the central Trinity Basin into Humboldt County and beyond where the South Fork Trinity River merges with the Trinity River, and the Trinity River weds with the Klamath River at the township of Weitchpec. Strong spatial-genetic structure combined with poor dispersal capabilities suggest that: 1) down river drifting on rafts of vegetation; 2) natural landslides and massive slope failures, characteristic of the historic China Slide near the junction of the Trinity River and New River; and 3) human-mediated construction and re-distribution of rocky soils and associated leaflitter along Highway 299 between the towns of Weaverville and Willow Creek, likely facilitated dispersal by the Trinity bristle snail across river systems in the Trinity Basin historically and in recent times.

\section{Taxonomic Designations}

Option 1: current taxonomy.-Based on results of the DNA sequence and qualitative morphological criteria two principal clades within the genus Monadenia were delineated (Cordero and Lindberg 2002; Roth and Sadeghian 2006). One clade was characterized morphologically by bristles on the surface of the shell at some time in the ontogeny of the species, which was designated as the Redwood sideband lineage consisting of three subspecies from eastern Humboldt, Siskiyou, and Trinity counties:

- Yellow-based sideband (M. i. ochromphalus (Berry 1937) - Counties: Del Norte, Siskiyou, and Humboldt, CA

- $\quad$ Trinity bristle snail (M. i. setosa (Talmadge 1952) - Counties: Trinity and Humboldt , CA

- $\quad$ Redwood sideband (M. i. subcarinata (Hemphill in Binney 1892) Counties: Humboldt, Trinity, CA

The second principal clade was characterized morphologically by not having bristles at any time in its ontogeny. Members of this clade were considered genetically diverse and likely contained at least two species, the most important of which was the Pacific sideband, which ranges from southeastern Alaska to southwestern Oregon and dips into California in Del Norte and likely Humboldt counties, and small sections of northwestern and northcentral Siskiyou County (Roth and Sadeghian 2006). Several taxa formerly regarded as subspecies of the Pacific sideband or as separate species, were hypothesized to belong to the Redwood sideband (Roth and Sadeghian 2006). If the current taxonomy within the Trinity bristle snail C-clade is embraced, then species and their subclade designations delineated in the present study corresponds to the classification provided by Roth and Sadeghian (2006) based largely on genetic criteria. This taxonomic classification consists of 14 species and 
20 subspecies of terrestrial sideband snails within the genus Monadenia, with the specific geographic range for each taxon delineated generally at the level of the county. There are no new morphological descriptions or keys to taxa in their checklist of land snails and slugs of California and adjacent areas in Oregon, as morphological descriptions reside within cited original descriptions sampled at the topotype. This reality includes subspecies contained within the Redwood sideband species-complex found within the greater Trinity Basin of northern California.

Option 2: new taxonomy.-Alternatively, the proposed new taxonomic classification includes 17 species and 24 subspecies and deviates significantly from the classification of Roth and Sadeghian (2006) in several respects (Table 5). First, the Trinity bristle snail and the Yellow-based sideband are retained as distinct species. Second, given that the Redwood sideband samples assayed were in fact the subspecies $M$. i. subcarinata, evidence provided here strongly justifies elevating this subspecies to species status as well. The traditional ranking of M. i. subcarinata as a subspecies of the Redwood sideband was made with respect to morphological attributes "typical" Redwood sideband specimens from farther south in California (Roth personal communication). Roth further suggested that based on the pattern of genetic divergence and speciation shown herein, that subcarinata is likely a "full" species. Third, genetic diversity was well-defined within disjunct subclades of the Redwood sideband (Clade-A) and the Trinity bristle snail (Clade-C), which merit subspecies status as indicated by: 1) high posterior probability and bGMYC scores delineated in the BEAST consensus tree (Fig. 8 and Fig. 9); 2) diversification within these genetic subunits concordant with geographic isolation and allopatric differentiation as a function of topographical and hydrological barriers to gene flow within the Trinity Basin; and 3) syntopic relationships among several subclades of both the Trinity bristle snail and the Redwood sideband with no apparent genetic intermingling as confirmed from the DNA phylograms. Subclade diversification within the Yellow-based sideband (Clade-B) does not warrant subspecific designation based on the sampling distribution in this study because DNA samples clustered together even though they were from opposite sides of the Klamath River near its headwaters.

The monotypic morphological condition for "bristles abundant" characteristic of the Swede Creek subclade and largely evident in the Hyampom subclade may simply be a result of genetic drift or founder effects (Cook 1998; Millstein 2008, 2009) with or without restricted gene flow between opposite sides of the central Trinity River, and which contributes to genetic patchiness on a small scale. Genetic subunits that made up the Hyampom subclade (Hyampom, Corral, Big creeks) were somewhat problematic because they were intermingled in the phylogram just like in the Redwood sideband. Although Corral Creek samples grouped or tended to group together in every phylogram all genetic units were grouped into one subspecies because they were not very divergent, and there were no major geographic barriers separating samples. Even though posterior probability and mtDNA diversity scores support splitting them up at least to the subspecies level, examination of their nuclear DNA would likely not support separating them into subspecies. So, for now genetic samples within the Hyampom subclade likely should be lumped together despite separate high posterior probability and bGMYC scores. The remaining subclades, however, all had 0.95 bGMYC as a probability score based on the BEAST consensus tree (Table 4) and were mostly allopatric in their geographic distribution in relation to topography and riverine barriers making it reasonable to designate them as separate and distinct subspecies. 
Table 5. Proposed new taxonomic classification modified from Roth and Sadeghian (2006). Data and conclusions derived from the present study includes 17 species and 24 subspecies of sidebands within the genus Monadenia. Counties in California and Oregon are indicated under geographic distribution.

\begin{tabular}{l} 
Species \\
\hline 1. Monadenia circumcarinata (Stearns 1879) \\
2. Monadenia mariposa Smith 1957 \\
3. Monadenia mormonum (Pfeiffer 1857) \\
(a) Monadenia m. buttoni (Pilsbry 1900) \\
(b) Monadenia m. cala (Pilsbry 1900) \\
(c) Monadenia m. hillebrandi (Newcomb 1864) \\
(d) Monadenia $m$. hirsuta (Pilsbry 1927) \\
(e) Monadenia m. new subspecies "I" \\
(f) Monadenia m. loweana Pilsbry 1927 \\
(g) Monadenia m. mormonum (Pfeiffer 1857)
\end{tabular}

4. Monadenia tuolumneana (Berry 1955

5. Monadenia yosemitensis (Lowe 1916)

6. Monadenia callipeplus (Berry 1940

7. Monadenia chaceana (Berry 1940

8. Monadenia cristulata Berry 1940

9. Monadenia fidelis (Gray 1834)

(a) Monadenia f. flava (Hemphill in Binney 1892)

(b) Monadenia f. leonina Berry 1937

(c) Monadenia f. pronotis Berry 1931

(d) Monadenia f. smithiana Berry 1940

10. Monadenia infumata (Gould 1855)

(a) Monadenia i. callidina Berry 1940

(b) Monadenia i. infumata (Gould 1855)

(c) Monadenia i. trinidadensis Talmadge 1947

11. Monadenia marmarotis Berry 1940

12. Monadenia ochromphalus Berry 1937

13. Monadenia setosa Talmadge 1952

(c) Monadenia s. new subspecies "China"

(b) Monadenia s. new subspecies "dyer"

(e) Monadenia s. new subspecies "hyampom"
Geographic distribution

Tuolumne

Mariposa

West-side Sierra Nevada

Calaveras

Calaveras

Tuolumne

Tuolumne

Calaveras and Tuolumne

Mariposa, Fresno

Tehama, Placer, El Dorado, Sacramento, Amador

Tuolumne

Mariposa, Madera, Fresno

Siskiyou

Southern OR to northern CA

Siskiyou

Pacific coast from SE Alaska to northern CA, west of the crest of Cascade Range

Siskiyou and southwest OR

Siskiyou and southern OR

Del Norte

Del Norte

Northern to central CA

Del Norte and Humboldt

Del Norte, Humboldt, Mendocino, Sonoma, Napa, Marin, Contra Costa, Alameda

Humboldt

Siskiyou and Trinity

Northern to central CA

Trinity County, eastern Humboldt County Trinity, W-side central Trinity River, vicinity of China landslide

Trinity, NE-side central Trinity River, NW-side New River

Trinity, W-side central Trinity River, N-side central South Fork Trinity River 
Table 5. continued

\begin{tabular}{cl}
\hline Species & Geographic distribution \\
\hline (a) Monadenia $s$. new subspecies "setosa" & Trinity, NE-side central Trinity River, \\
& Type Locality at Swede Creek. \\
(d) Monadenia s. new subspecies "southfork" & Trinity, Humboldt, W-side South Fork \\
& Trinity River, Friday Ridge Rd.
\end{tabular}

14. Monadenia subcarinata (Hemphill in Binney 1892) Northern to central CA

(a) Monadenia s. new subspecies "hyampom"

Trinity, west-central Trinity county and between the central Trinity River, vicinity of Hayfork Creek, headwaters of South Fork Trinity River, and the eastern slope of South Fork Mountain

(b) Monadenia s. new subspecies "southfork"

Humboldt County, west-side of the South Fork Trinity River at Big Creek and Fourmile Creek

(c) Monadenia s. new subspecies "swede"

15. Monadenia, new species " $m$ "

Trinity, northeast-side of the central Trinity River at Swede Creek and Little Swede Creek

Del Norte

16. Monadenia churchi Hanna and Smith 1933

Siskiyou, Trinity, Shasta, Tehama, Mendocino, Glenn, Lake

17. Monadenia troglodytes Hanna and Smith 1933

Shasta

(a) Monadenia t. troglodytes Hanna and Smith 1933

Shasta, Late Pleistocene - Early Holocene

(b) Monadenia t. wintu Roth 1981

Shasta

\section{Conclusions}

In general, taxonomy, distribution, critical microhabitat requirements, and habitatarea relationships of endemic populations of terrestrial gastropods are poorly known within the California-Cascades Province. This phenomenon is directly associated with isolation due to topographic and physiographic ${ }^{16}$ diversity in the landscape in combination with low vagility, small, fragmented populations, and restricted geneflow. These environmental attributes function to facilitate allopatric differentiation leading to elevated levels of species diversity, as well as extinction. There are $\sim 117$ special status species of gastropods on the CDFW 2020 Special Animals List (CDFW 2020). Of these, $~ 66.7 \%$ are terrestrial snails. Surprisingly, the only saltwater, freshwater, or terrestrial species listed (threatened or endangered) under CESA is the Trinity bristle snail, even though very little is known about the distribution, systematics and ecology, life-history, and genetics of other rare and endemic species in northern California. Currently, the only other endemic terrestrial snail listed in California is the Morro shoulderband or Banded dune snail (Helminthoglypta walkeriana), which is listed as Endangered under the ESA(USFWS 1973). Herein, this study provides: 1) a proactive quantitative approach to species and subspecies assessment based on scientifically credible genetic, systematic, biogeographic, and taxonomic information aimed at facilitating effective management and conservation of State-listed species under CESA; and 2) a template for addressing future taxonomic assessments and status reviews

\footnotetext{
${ }^{16}$ A distinct type of landscape, landform, geology, and evolutionary history.
} 
of special status species of other terrestrial gastropods as part of CDFW's commitment to the California Biodiversity Initiative.

As noted by Barnosky et al. (2011), the ongoing rapid decline in biodiversity has been called the sixth mass extinction, and the need to reverse this trend has never been more important. Globally, terrestrial gastropods are one of the most diverse groups of land animals (Lydeard et al. 2004) ever to occupy the Planet, with 24,000 described species inhabiting a large range of habitats (Nicolai and Ansart 2017). Of these 1,105 species worldwide are on the IUCN red list as extinct, critically endangered, endangered, or vulnerable (www. iucnredlist.org; Nicolai and Ansart 2017). Mollusks as a group have suffered the highest number of extinctions of any other taxonomic assemblage. Forty-two percent $(n=693)$ of recorded extinctions of animal species since 1500 were mollusks; $99 \%$ of which included both terrestrial and freshwater species (Seddon 1998; Lydeard et al. 2004). Many species of mollusks listed by the IUCN are in the "Data Deficient" category (IUCN 2001). This means that information is either absent or lacking regarding the current geographic range, rate of population decline, degree of threat, or that current critical habitat is unknown (Dunk et al. 2004). The Trinity bristle snail is no exception, as are most other taxa on the Special Animal List for CDFW. Continued lack of priority planning at delineating biological diversity within terrestrial mollusks limits funding and our ability to gauge the extent of degradation to biological and ecological ecosystems throughout the State.

Terrestrial gastropods as a group play an integral role in facilitating natural ecosystem function. They aid in decomposition, nutrient cycling and soil-building of forest, woodland, and grassland vegetation through foraging (Mason 1970a and 1970b; Jennings and Barkham 1979; Richter 1979; Nystrand and Granstrom 1997; Pratheret al. 2013). And most species are major components in mulch and litter communities essential in maintaining soil fertility (Swift et al. 1979). It was estimated that terrestrial mollusks active on the floor of northern boreal forests accounted $>6 \%$ of the recycled energy in those forests (Hawkins et al. 1977; Dunk et al. 2004). Terrestrial gastropods provide food and essential nutrients to other wildlife (South 1980; Churchfield 1984; Frest and Johannes 1995; Sullivan 1995; Martin 2000; Nyffeler and Symondson 2001) and contribute greatly to plant community structure and diversity (Hulme 1996; Peters 2007). Many terrestrial gastropods are intermediate hosts of terrestrial parasites and some function as vectors for pathogens (Ball et al. 2001, Barker 2002; Cowie 2011; Rowley et al. 1987; Graeff-Teixeira 2007). Agriculturally, many species are serious pests that lead to crop damage and the spread of pesticide residue, while negatively impacting native habitats and endemic biodiversity.

Notably, both aquatic and terrestrial gastropods are potentially valuable indicators of climate change but the physiological responses in this group to changing climate are not well understood. With climate change terrestrial ectotherms are expected to be especially vulnerable to changes in temperature and regional water regimes owing to extreme weather events, particularly in temperate regions (Nicolai and Ansart 2017). Understanding the effect of climate change on soil fertility in forest, woodland, and grassland ecosystems of northern California in relation to the role played by communities of terrestrial gastropods is a preamble to safeguarding soil function (Swift et al. 1979). This need is particularly relevant given that as a group terrestrial gastropods constitute $\sim 66.7 \%$ of all taxa on the California Special Animals List, a point that needs to be continually emphasized to resource agencies mandated with the responsibility of managing regional biodiversity consistent with the California's Biodiversity Initiative. 


\section{ACKNOWLEDGEMENTS}

This study is dedicated to Rhianna Lee, Senior Environment Scientist, Wildlife Biologist, and Friend, whose genuine commitment to the resource and to "Doing Good Things for Wildlife" is greatly missed. For assistance with collection of specimens and habitat data, special thanks are extended to Rhianna Lee and Andrew Yarusso (CDFW Timber Program). I thank Keith Hamm, Nadine R. Kanim (USFWS-Yreka), Shawn Fresz (CDFW Wildlife/ Lands Program), and two anonymous reviewers for providing numerous, relevant, and helpful suggestions on the document. Dr. Alex Van Dam conducted the DNA assays at the Department of Animal Science, University of California Davis. Jill Wright (USFWS) made it happen by providing invaluable administrative support when others sought to scuttle the project. Curt Babcock (CDFW Habitat Conservation Program) provided extended funding in support of the Project. John Hileman (CDFW Trinity River Project, Fish Program) continues to provide a stimulating environment for scientific discourse as applied to adaptive management, as well as daily harassment during the process of developing numerous documents. I am particularly grateful for the financial support and assistance provided by the USFWS (Project T-21-1 [Project C]) through the State Wildlife Grant (SWG) Program, made available to the California Department of Fish and Wildlife, Region 1.

\section{LITERATURE CITED}

Anderson, M. J. 2017. Permutational multivariate analysis of variance (PERMANOVA). Wiley StatsRef: Statistics Reference Online. John Wiley and Sons, Ltd. Available from: https://doi.org/10.1002/9781118445112.stat07841

Armijo, P. 1979. Monadenia setosa (California Northern River Snail) Interim Species Management Plan, U. S. Forest Service \#2670 - Surveys, Studies, Plans.

Bailli, J., and B. Groombridge. 1996. 1996 IUCN Red List of threatened Animals. Internal Union for the Conservation of Nature, Gland, Switzerland.

Ball, M. C., M. W. Lankester, and S. P. Mahoney. 2001. Factors affecting the distribution and transmission of Elaphostrongylus rangiferi (Protostrongylidae) in caribou (Rangifer tarandus caribou) of Newfoundland, Canada. Canadian Journal of Zoology 79:1265-1277.

Barker, G. M. 2002. Mollusks as crop pests. CABI Publishing, Wallingford, UK.

Barnosky, A. D., N. Matzke1, S. Tomiya1, G. O. U. Wogan, B. Swartz, T. B. Quental, C. Marshall, J. L. McGuire, E. L. Lindsey, K. C. Maguire, B. Mersey, and E. A. Ferrer. 2011. Has the Earth's Sixth Mass Extinction Already Arrived? Nature 471:51-57.

Barraclough, T. G., and S. Nee. 2001. Phylogenetics and speciation. Trends in Ecology and Evolution 16:391-399.

Becker, S. , R. Hanner, and D. Steinke. 2011. Five years of FISH-BOL: Brief status report. Mitochondrial DNA 22:3-9.

Benjamini, Y., and Y. Hochberg. 2000. On the adaptive control of the false discovery rate in multiple testing with independent statistics. Journal of Educational and Behavioral Statistics 25:60-83.

Cain, A. J., and J. D. Currey. 1963. Area effects in Cepaea. Philosophical Transactions of the Royal Society of London Series B, Biological Sciences 246:1-81.

California Department of Fish and Wildlife (CDFW). 1972. California Endangered 
Species Act (CESA). Available from: https://nrm.dfg.ca.gov/FileHandler. ashx? DocumentID=109406\&inline

California Department of Fish and Wildlife (CDFW). 2020. California Department of Fish and Wildlife, Natural Diversity Database. Special Animals List. Periodic publication. Available from: http://nrm.dfg.ca.gov/FileHandler. ashx?DocumentID=109406\&inline

Cameron, R. A. D., L. M. Cook, and J. J. D. Greenwood. 2013. Change and stability in a steep morph-frequency cline in the snail Cepaea nemoralis (L.) over 43 years. Biological Journal of the Linnean Society108:473-483.

Churchfield, S. 1984. Dietary separation in three species of shrew inhabiting water-cress beds. Journal of Zoology 204:211-228.

Cook, L. M. 1998. A two-stage model of Cepaea polymorphism. Philosophical Transactions of the Royal Society of London Series B, Biological Sciences 353:15771593.

Corder, G. W., and D. I. Foreman. 2014. Nonparametric statistics: a step-by-step approach, John Wiley and Sons, Inc., Hoboken, NJ, USA.

Cordero, A. M., and D. L. Lindberg. 2002. Molecular phylogeny of some land snails of the clades Monadenia and Helminthoglypta in southern Oregon and Northern California. Final Report submitted to Bureau of Land Management District Office, Roseburg District Office., in partial fulfillment of Purchase Order No. HRP000506.

Cowie, R. H. 2011. Snails and slugs. Pages 634-643 in D. Simberloff and M. Rejmanek, editors, Encyclopedia of Biological Invasions. University of California Press, Berkeley, CA, USA.

Davison, A., and B. Clarke. 2000. History or current selection? A molecular analysis of 'area effects' in the land snail Cepaea nemoralis. Proceedings of the Royal Society B 267:1399-1405.

Drummond, D. J., and A. Rambaut. 2007. BEAST: Bayesian evolutionary analysis by sampling trees. BMC Biology 7:214.

Drummond, A. J., and M. A. Suchard. 2010. Bayesian random local clocks, or one rate to rule them all. BMC Biology 8:114.

Dunk, J. R. W. J. Zielinski, and H. K. Preisler. 2004. Predicting the occurrence of rare mollusks in Northern California forests. Ecological Applications 14:713-729.

Edgar, R. C. 2004. Muscle: multiple sequence alignment with high accuracy and high throughput. Nucleic Acids Research 32:1792-1797.

Everitt, B. S., and T. Hothorn. 2011. An introduction to applied multivariate analysis with R. Springer, New York, NY, USA.

Fiorentino, V., N. Salomone, G. Manganelli, and F. Giusti. 2008. Phylogeography and morphological variability in land snails: the Sicilian Marmorana (Pulmonata, Helicidae). Biological Journal of the Linnean Society 94:809-823.

Frest, T. J., and E. J. Johannes. 1995. Interior Columbia Basin mollusk species of special concern. Deixis Consultants, Seattle, WA, USA. Prepared for the U.S. Department of Agriculture, Forest Service, U.S. Department of the Interior, Bureau of Land Management, Upper Columbia River Basin Ecosystem Management Project.

Frest, T. J., and E. J. Johannes. 2000. A Baseline mollusk survey of southwestern Oregon, with emphasis on the Rogue and Umpqua river drainages. Deixis Consultants, Seattle, WA, USA. 
Futuyma, D. J. 2009. Evolution. Sinauer Associates, Sunderland, MA, USA.

Gladstone, N. S., M. L. Niemiller, E. B. Pieper, K. E. Dooley, and M. L. McKinney. 2019. Morphometrics and phylogeography of the cave-obligate land snail Helicodiscus barri (Gastropoda, Stylommatophora, Helicodiscidae). Subterranean Biology 30:1-32.

Goodfriend, G. A. 1986. Variation in land-snail shell form and size and its causes: a review. Systematic Zoology 35:204-223.

Graeff-Teixeira, C. 2007. Expansion of Achatina fulica in Brazil and potential increased risk for angiostrongyliasis. Transactions of the Royal Society of Tropical Medicine and Hygiene 101:743-744.

Groombridge, B. 1994. IUCN red List of Threatened Animals. International Union for Conservation of Nature, Gland, Switzerland.

Harrison, R. G., and E. L. Larson. 2014. Hybridization, introgression, and the nature of species boundaries. Journal of Heredity 105:795-809.

Hasegawa, M., H. Kishino, and T. Yano. 1985. Dating of the human-ape splitting by a molecular clock of mitochondrial DNA. Journal of Molecular Evolution 22:160-74.

Hawkins, J. W., M. Lankester, R. A. Lautenschlager, and F. W. Bell. 1977. Length-biomass and energy relationships of terrestrial gastropods in northern forest ecosystems. Canadian Journal of Zoology 75:501-505.

Hudson, R. R. 1990. Gene genealogies and coalescent process. Pages 1-44 in D. J. Futuyma and J. Antonivics, editors. Oxford Surveys in Evolutionary Biology. Oxford University Press, Oxford, UK.

Jennings, T. J., and J. P. Barkham. 1979. Litter decomposition by slugs in mixed deciduous woodland. Holarctic Ecology 2:21-29.

Jones, J. S. , R. K. Selander, and G. D. Schnell. 1980. Patterns of morphological and molecular polymorphism in the land snail Cepaea nemoralis. Biological Journal of the Linnean Society 14:359-387.

Kocher, T. D., W. K. Thomas, A. Meyer, S. V. Edwards, S. Paabo, F. X. Villablanca, and A. C. Wilson. 1989. Dynamics of mitochondrial DNA evolution in animals: Amplification and sequencing with conserved primers. Proceedings of the National Academy of Sciences of 86:6196-6200.

Liang, L., S. Wu, and L. Yu. 2015. Coalescent methods for estimating species trees from phylogenomic data. Journal of Systematics and Evolution 53:380-390.

Liu K., C., R. Linder, and T. Warnow. 2011. RAxML and FastTree: comparing two methods for large-scale maximum likelihood phylogeny estimation. PLoS ONE 6:e27731.

Lydeard, C., R. H. Cowie, R. H. Ponder, W. F. Bogan, A. E. Bouchet, P. S. A. Clark, K. S. Cummings, T. J. Frest, O. Gargominy, and D. G. Herbert. 2004. The global decline of nonmarine mollusks. BioScience 54:321-330.

Maddison, W. P., and D. R. Maddison. 2019. Mesquite: a modular system for evolutionary analysis. Version 3.61: Available from: http://www.mesquiteproject.org.

Martin, S. M. 2000. Terrestrial snails and slugs (Mollusca: Gastropoda) of Maine. Northeast Naturalist 7:33-88.

Mason, C. F. 1970a. Food, feeding rates and assimilation in woodland snails. Oecologia $4: 358-373$.

Mason, C. F. 1970b. Snail populations, beech litter production, and the role of snails in litter decomposition. Oecologia 5:215-239. 
Mayr, E. 1969. Principles of systematic zoology. McGraw-Hill Inc., New York, NY, USA.

Miller, J. P. 2016. Geometric morphometric analysis of the shell of Cerion mumia (Pulmonata: Cerionidae) and related species. Folia Malacologica 24:239-250.

Millstein, R. L. 2008. Distinguishing drift and selection empirically: 'The Great Snail Debate' of the 1950s. Journal of the History of Biology 41:339-367.

Millstein, R. L. 2009. Concepts of drift and selection in 'The Great Snail Debate' of the 1950s and early 1960s. Transactions of the American Philosophical Society 99:271-298.

Nee, S., R. M. May, and P. H. Harvey. 1994. The reconstructed evolutionary process. Philosophical Transactions of the Royal Society B 344:305-311.

Nicolai, A., and A. Ansart. 2017. Conservation at a slow pace: terrestrial gastropods facing fast-changing climate. Conservation Physiology 5:1-17.

Nyffeler, M., and W. O. P. Symondson. 2001. Spiders and harvestmen as gastropod predators. Ecological Entomology 26:617-628.

Nystrand, O., and A. Granstrom 1997. Forest floor moisture controls predator activity on juvenile seedlings of Pinus sylvestris. Canadian Journal of Forest Research 27:1746-1752.

Ożgo, O., and M. T. Kinnison. 2008. Contingency and determinism during convergent contemporary evolution in the polymorphic land snail, Cepaea nemoralis. Evolutionary Ecological Research 10:721-733.

Palumbi, S. R. 1996. Nucleic acids II: the polymerase chain reaction. Pages 205-247 in D. M. Hillis, C. Moritz, and B. K. Mable, editors. Molecular Systematics. Sinauer Associates, Inc., Sunderland, MA, USA.

Perez, K. E., and J. R. Cordeiro. 2008. A Guide for Terrestrial Gastropod Identification. Proceedings of the Terrestrial Gastropod Identification Workshop. Southern Illinois University, Carbondale, IL, USA.

Phillips, J. D., D. J. Gillis, and R. H. Hanner. 2019. Incomplete estimates of genetic diversity within species: Implications for DNA barcoding. Ecology and Evolution 9:2996-3010.

Pratheret, C. M., S. L. Pelini, A. Laws, E. Rivest, M. Woltz, C. P. Bloch, I. Del Toro I, C. K Ho, J. Kominoski, and T. A. S. Newbold. 2013. Invertebrates, ecosystem services and climate change. Biological Review 88:327-348.

R Core Team. 2020. R: A language and environment for statistical computing. R Foundation for Statistical Computing, Vienna, Austria. Available from: https://www.Rproject.org/

Rambaut A. 2009. FigTree version 1.4.1 [computer program]: Available from: http://ree. bio.ed.ac.uk

Rambaut, E. S., Drummond, D. Xie, G. Bael, and M. A. Suchard. 2018. Posterior summarization in bayesian phylogenetics using tracer 1.7. Systematic Biology 67:901904.

Razkin, O., B. J. Gomez-Moliner, K. Vardinoyannis, A. Martinez-Orti, and M. J. Madeira. 2017. Species delimitation for cryptic species complexes: case study of Pyramidula (Gastropoda, Pulmonata). Zoologica Scripta 46:55-72.

Reid, N. M., and B. Carstens. 2012. Phylogenetic estimation error can decrease the accuracy of species delimitation: a Bayesian implementation of the general mixed Yule-coalescent model. BMC Evolutionary Biology 12:196. 
Richter, K. O. 1979. Aspects of nutrient cycling by Ariolimax columbianus (Mollusca: Arionidae) in Pacific Northwest coniferous forests. Pedobiologia 19:60-74.

Ronquist, F., M. Teslenko, P. van der Mark, D. L. Ayres, A. Darling, S. Höhna, B. Larget, L. Liu, M. A. Suchard, and J. P. Huelsenbeck. 2012. MrBayes 3.2: Efficient bayesian phylogenetic inference and model choice across a large model space. Systematic Biology 61:539-542.

Roth, B. 1972. Rare and endangered land mollusks in California. Sterkiana 48:4-16.

Roth, B. 1978. Biology and distribution of Monadenia setosa Talmadge. Report to U.S. Forest Service, Shasta-Trinity National Forest, Redding, CA, USA.

Roth, B. 1982. Life history studies and distribution of Monadenia setosa. Report submitted to USDA Forest Service, Shasta-Trinity National Forest, Redding CA, USA.

Roth, B. 1993. Critical review of terrestrial mollusks associated with late-successional and old-growth forests in the range of the northern spotted owl. Final report to Forest Ecosystem Management Working Group, U.S. Forest Service, Redding, CA, USA.

Roth, B. 1996. Monadenia setosa. The IUCN red list of threatened species 1996: e.T13666A4324507.

Roth, B. 2002. Taxonomy and classification of Monadenia, BLM contract purchase order HAB020406. U.S. Bureau of Land Management, Portland, OR, USA.

Roth, B., and L. L. Eng. 1980. Distribution, ecology, and reproductive anatomy of a rare land snail. Monadenia setosa, Talmage. California Fish and Game 66:4-16.

Roth, B., and P. H. Pressley. 1986. Observations on the range and natural history of Monadenia setosa (Gastropoda: Pulmonata) in the Klamath Mountains, California, and the taxonomy of some related species. The Veliger 29:169-182.

Roth, B., and P. S. Sadeghian. 2006. Checklist of the land snails and slugs of California. Second edition. Santa Barbara Museum of Natural History, Contributions in Science Number 3.

Rowley, M. A., E. S. Loker, J. F. Pagels, and R. J. Montali. 1987. Terrestrial gastropod hosts of Parelaphostrongylus tenuis at the National Zoological Park's Conservation and Research Center, Virginia. Journal of Parasitology 73:1084-1089.

Seddon, P. J., and P. S. Soorae. 1999. Guidelines for subspecific substitutions in wildlife restoration projects. Conservation Biology 13:177-184.

Silvertown, J. L., M. Cook, R. A. D. Cameron, M. Dodd, K. McConway, J. Worthington, P. Skelton, C. Anton, O. Bossdorf, B. Baur, M. Schilthuizen, B. Fontaine, H. Sattmann, G. Bertorelle, M. Correia, C. Oliveira, B. M. Pokryszko, M. Oz go, A. Stalazs, E. Gill, U. Rammul, P. Solymos, Z. Feher, and X. Juan. 2011. Citizen science reveals unexpected continental-scale evolutionary change in a model organism. PLoS ONE 6:e18927.

Smartt, R. A, and R. M. Sullivan. 1990. Distribution and ecology of Pecosorbis kansasensis in eastern New Mexico. Journal of Arid Environments 19:181-187.

Smith, U. E., and J. R. Hendricks. 2013. Geometric morphometric character suites as phylogenetic data: extracting phylogenetic signal from gastropod shells. Systematic Biology 62:366-385.

South, A. 1980. A technique for the assessment of predation by birds and mammals on the slug Deroceras reticulatum (Muller) (Pulmonata: Limacidae). Journal of Conchology 30:229-234. 
U.S. Fish and Wildlife Service (USFWS). 1973. Endangered Species Act of 1973. Available from: https://www.fws.gov/laws/lawsdigest/ESACT.HTML

U.S. Forest Service and the U.S. Bureau of Land Management (USFS and USBLM). 1994. Final supplemental environmental impact statement on management of habitat for late-successional and old-growth forest related species within the range of the northern spotted owl. Washington, DC. Available from: https://archive.org/ details/finalsupplementa03v1 unit/page/n29/mode/2up

Stamatakis, A. 2014. RAxML Version 8: A tool for phylogenetic analysis and post-analysis of large phylogenies. Bioinformatics 30:1312-1313.

Stankowski, S. 2011. Extreme, continuous variation in an island snail: local diversification and association of shell form with the current environment. Biological Journal of the Linnean Society 104:756-769.

Steinke, D., and R. Hanner. 2011. The FISH-BOL collaborators' protocol. Mitochondrial DNA 22:10-14.

Sullivan, R. M., and R. A. Smartt. 1995. Genetics, ecology, and conservation of woodland snails (genus Ashmunella) on White Sands Missile Range, New Mexico. Department of Defense, U.S. Army, White Sands Missile Range.

Sullivan, R. M. 1995. Micro-evolutionary differentiation and biogeographic structure among coniferous forest populations of the Mexican wood rat (Neotoma mexicana) in the American southwest: A test of the vicariance hypothesis. Journal of Biogeography 21:369-389.

Sullivan, R. M. 1996. Ecology, microhabitat assessment, and endangered species management of federal species of concern terrestrial gastropods in southern New Mexico. New Mexico Department of Game and Fish, Endangered Species Program.

Sullivan, R. M. 1997. Conservation status assessment and population monitoring of federal candidate land snails of southern New Mexico. T and E, Inc., Las Cruces, NM, USA.

Sullivan, R. M. 2021. Distribution, ecology, and genetics of the Trinity bristle snail in northern California: management and conservation strategies. California Department of Fish and Wildlife Report (in preparation).

Swift, M. J., O. W. Heal, and J. M. Anderson. 1979. Decomposition in terrestrial ecosystems. Blackwell Scientific Publications, Oxford, UK.

Talmadge, R. R. 1952. A bristled Monadenia from California. The Nautilus 66:47-50.

Talavera, G., V. Dincă, and R. Vila. 2014. Factors affecting species delimitations with the GMYC model: insights from a butterfly survey. Methods in Ecology and Evolution 4:1101-1110.

Tavaré, S. 1986. Some probabilistic and statistical problems in the analysis of DNA sequences. Lectures on Mathematics in the Life Sciences 17:57-86.

Uit de Weerd D, W. H. Piel, and E. Gittenberger. 2004. Widespread polyphyly among Alopiinae land snail genera: when phylogeny mirrors biogeography more closely than morphology. Molecular Phylogenetics and Evolution 33:533-548.

Walton, M. L. 1963. Length of life in west American land snails. The Nautilus 76:127-131.

Submitted 30 September 2020

Accepted 24 November 2020

Associate Editor was R. La Rosa 
Appendix I. Reconstruction of the Cordero and Lindberg (2002) phylogram showing hypothesized relationships among species and clades within the genus Monadenia that included samples from various counties in northern California (Siskiyou, Humboldt, and Trinity). Numbers in parentheses identify individual samples. Their Group B denotes the "bristled clade in which bristles on the shells were present some time during ontogeny". Their Cgroup consists exclusively of M. f. subcarinata except for the one specimen (\#19) labeled as $M$. setosa from the type locality at Swede Creek. Their D-group consists exclusively of M. f. ochromphalus from Siskiyou County. The species name M. fidelis (Pacific sideband) used in their phylogram has been changed to M. infumata (Redwood sideband; Roth and Sadeghian 2006). This reconstruction corresponds to their Attachment 4 (Monadenia Trees, D. Phylogram [Tree 33] 16S+COI, mtDNA).

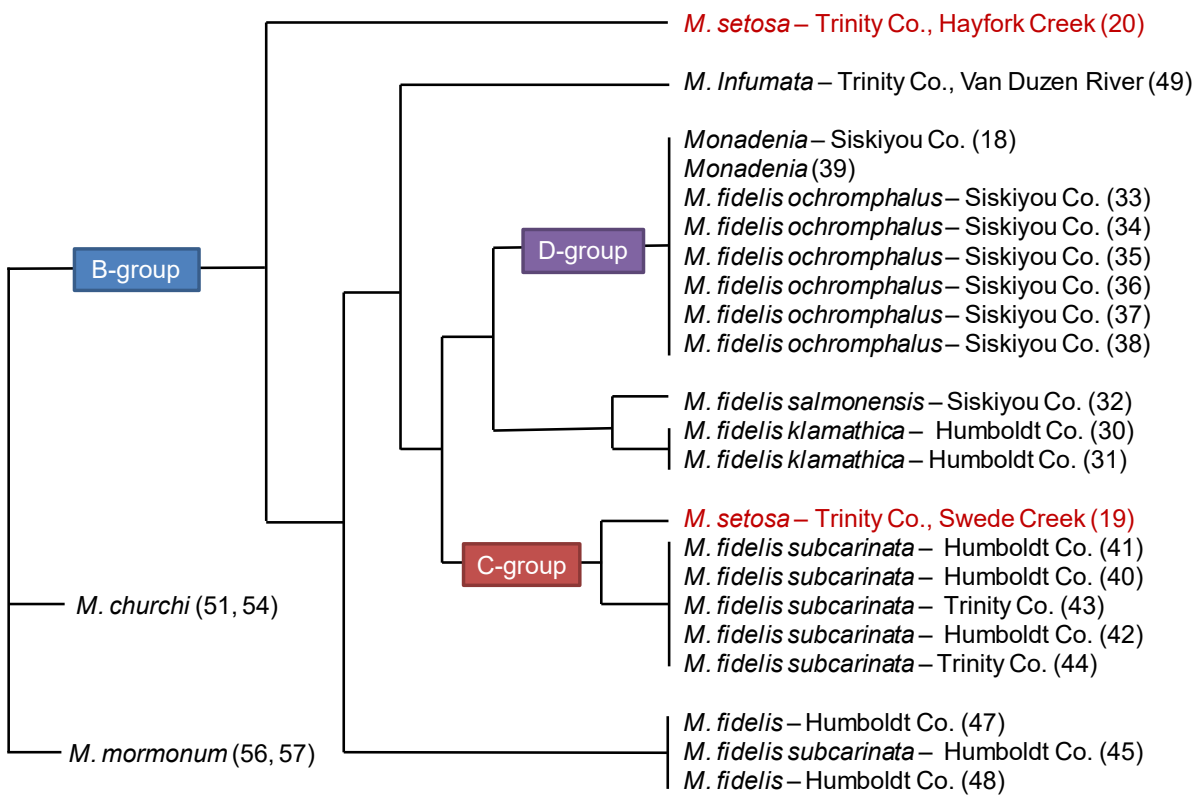

